\title{
Roles of the functional loss of $p 53$ and other genes in astrocytoma tumorigenesis and progression ${ }^{1}$
}

\author{
Michimasa Nozaki, Mitsuhiro Tada, Hiroyuki Kobayashi, Chang-Liang Zhang, \\ Yutaka Sawamura, Hiroshi Abe, Nobuaki Ishii, and Erwin G. Van Meir ${ }^{2}$ \\ Department of Neurosurgery [M.N., M.T., H.K., C.-L.Z., Y.S., H.A.], Division of Cell Biology [M.T.], \\ Cancer Institute, Hokkaido University School of Medicine, Kitaku, Sapporo 060-8638, Japan; \\ Laboratory of Tumor Biology and Genetics, Department of Neurosurgery, University Hospital (CHUV), \\ 1011 Lausanne, Switzerland [N.I., E.G.V.M.]; and Laboratory of Molecular Neuro-Oncology, Department \\ of Neurological Surgery, and Winship Cancer Center, Emory University, Atlanta, GA 30322 [E.G.V.M.]
}

Loss of function in the $p 53$ tumor suppressor gene due to mutation occurs early in astrocytoma tumorigenesis in about $30-40 \%$ of cases. This is believed to confer a growth advantage to the cells, allowing them to clonally expand due to loss of the p53-controlled $\mathrm{G}_{1}$ checkpoint and apoptosis. Genetic instability due to the impaired ability of p53 to mediate DNA damage repair further facilitates the acquisition of new genetic abnormalities, leading to malignant progression of an astrocytoma into anaplastic astrocytoma. This is reflected by a high rate of p53 mutation $(60-70 \%)$ in anaplastic astrocytomas. The cell cycle control gets further compromised in astrocytoma by alterations in one of the $\mathrm{G}_{1} / \mathrm{S}$ transition control genes, either loss of the $p 16 / C D K N 2$ or $R B$ genes or amplification of the cyclin $\mathrm{D}$ gene. The final progression process leading to glioblastoma multiforme seems to need additional genetic abnormalities in the long arm of chromosome 10; one of which is deletion and/or functional loss of the PTEN/MMAC1 gene. Glioblastomas also occur as primary (de novo) lesions in patients of older age, without $p 53$ gene loss but with amplification of the epidermal growth factor receptor (EGFR) gene. In contrast to the secondary glioblastomas that evolve from

Received 28 August 1998, accepted 3 December 1998.

${ }^{1}$ This work was supported by the Swiss National Science Foundation, the Swiss Anti-Cancer Foundation (E.G.V.M.), and MBNA, NA.

${ }^{2}$ Address correspondence and reprint requests to Mitsuhiro Tada, M.D., Division of Cell Biology, Cancer Institute, Hokkaido University School of Medicine, N-15 W-7, Kitaku, Sapporo 060-8638, Japan.

${ }^{3}$ Abbreviations used are as follows: CDK, cyclin-dependent kinase. astrocytoma cells with p53 mutations in younger patients, primary glioblastomas seem to be resistant to radiation therapy and thus show a poorer prognosis. The evaluation and design of therapeutic modalities aimed at preventing malignant progression of astrocytomas and glioblastomas should now be based on stratifying patients with astrocytic tumors according to their genetic diagnosis. Neuro-Oncology 1, 124-137, 1999 (Posted to Neuro-Oncology [serial online], Doc. 98-17, April 30, 1999. URL <neuro-oncology.mc.duke.edu>)

$\mathrm{M}$ utations in the $p 53$ tumor suppressor gene occur in about one-half of all human cancers. p53 protein functions as a DNA binding factor and can activate transcription through binding to specific sequences on target genes. It can also repress transcription through protein-protein interaction with the TATA-binding protein. p53 has been called the "guardian of the genome" because it promotes DNA repair processes by arresting cells with DNA damage in the $\mathrm{G}_{1}$ phase of the cell cycle. Alternatively, p53 can also induce cell death by activating apoptosis when irreparable genomic injuries have occurred. Loss of $\mathrm{p} 53$ functions, therefore, brings uninhibited growth, genetic instability, and immortalization in cells, leading to neoplastic transformation.

In the CNS, p53 mutation is frequently found in astrocytic tumors and, to a lesser degree, in primary malignant lymphomas. In this article, we discuss the roles of p53 mutation in the tumorigenesis and malignant progression of astrocytic tumors and relate it to other genetic alterations occurring in these tumors. 


\section{Evidence for the Involvement of p53 in Astrocytoma Tumorigenesis}

There have been several lines of evidence showing that loss of p53 function plays a definite role in astrocytoma tumorigenesis. p53 (-l-) astrocytes derived from p53 knockout mice show an increased growth rate and become spontaneously immortalized in successive cultures. On the other hand, astrocytes with hemizygous p53 alleles appear normal until a clone that loses the remaining wild-type allele emerges in the population (Bögler et al., 1995). These observations show that loss of $\mathrm{p} 53$ function confers an in vitro growth advantage on astrocytes. After several passages, p53 (-l-) astrocytes become aneuploid and transformed, as evidenced by their growth in soft agar, serum-free medium or in nude mice; whereas cells with wild-type p53 function never transform after in vitro passaging. This suggests that genetic instability due to p53 loss facilitates the occurrence of other genetic abnormalities necessary for transformation (Bögler et al., 1995; Yahanda et al., 1995).

Li-Fraumeni syndrome, caused by a germline mutation in one $p 53$ allele, serves as a natural experiment in humans. This syndrome is characterized by the frequent occurrence of malignant tumors early in life (Malkin et al., 1990), including astrocytomas. Patients with multifocal gliomas are also shown to harbor a high frequency of germline $p 53$ alterations (Kyritsis et al., 1994). These data support the concept that loss of $p 53$ function is an early event in astrocytoma tumorigenesis.

Another piece of evidence is that the neoplastic phenotype of astrocytic tumor cells can be reverted by restoration of p53 function. Transduction of wild-type p53 genes in p53-deficient glioblastoma cells results in growth arrest and/or apoptosis (Gomez-Manzano et al., 1997; Mercer et al., 1990; Van Meir et al., 1995).

\section{Prevalence of $p 53$ Mutations and 17p Loss of Heterozygosity in Astrocytic and Nonastrocytic Neoplasms}

We have applied a novel p53 functional assay in yeast to analyze $p 53$ status in astrocytic and nonastrocytic tumors (Flaman et al., 1995). This assay can accurately detect inactivating p53 mutations as red yeast colonies, does not detect polymorphisms, and in our hands is more reliable than previous conventional methods (Kashiwazaki et al., 1997; Waridel et al., 1997). This assay tests the transcriptional competence of p53 complexes synthesized on p53 cDNA generated by reverse transcriptase-polymerase chain reaction from tumor. p53 gene mutations were exclusively found in astrocytic neoplasms and primary malignant lymphomas (Nozaki et al., 1998). The results for astrocytic tumors are shown in Table 1 and compared with the previously documented p53 mutations and loss of heterozygosity data on chromosome $17 \mathrm{p}$. With this assay, we did not detect any inactivating mutations in 16 cases of World Health Organization grade I pilocytic astrocytoma (Ishii et al., 1998). Together with the previous DNA structure-based analyses that reported a rare occurrence of p53 mutations and the fact that pilocytic astrocytomas only rarely undergo progression to a higher grade (Kleihues et al., 1993), we

Table 1. Prevalence of $p 53$ mutation and chromosome $17 \mathrm{p} \mathrm{LOH}$ in astrocytomas by conventional techniques and yeast p53 functional assay

\begin{tabular}{|c|c|c|c|c|c|}
\hline \multirow[b]{2}{*}{ Technique } & \multicolumn{4}{|c|}{ WHO grade ${ }^{a}$} & \multirow[b]{2}{*}{ References } \\
\hline & $1^{b}$ & $1 I^{b}$ & $\mathrm{III}^{\mathrm{b}}$ & $\mathrm{IV}^{\mathrm{b}}$ & \\
\hline $\begin{array}{l}\text { Previous conventional series } \\
\text { p53 Mutation } \\
\text { 17p LOH }\end{array}$ & $\begin{array}{l}3 / 99(3) \\
7 / 23(30)\end{array}$ & $\begin{array}{c}14 / 122(11) \\
9 / 53(17)\end{array}$ & $\begin{array}{c}53 / 175(30) \\
28 / 66(42)\end{array}$ & $\begin{array}{c}143 / 526(27) \\
70 / 270(26)\end{array}$ & $\begin{array}{l}\text { Chozick et al., 1994; Chung et al., } \\
\text { 1991; Frankel et al., 1992; Fults et al., } \\
\text { 1992; Hayashi et al., 1997; Hunter et } \\
\text { al., 1993; Lang et al., 1994b; Litofsky } \\
\text { et al., 1994; Louis et al., 1993a; Louis } \\
\text { et al., 1993b; Mashiyama et al., 1991; } \\
\text { Matsumoto et al., 1998; Newcomb et } \\
\text { al., 1993; Ohgaki et al., 1993; Patt et } \\
\text { al., 1996; Rainov et al., 1995; Rasheed } \\
\text { et al., 1994; Sarkar et al., 1994; } \\
\text { Saxena et al., 1992; Schiffer et al., } \\
\text { 1995; Sure et al., 1997; Tada et al., } \\
\text { 1998; Tenan et al., 1994; Tsuzuki et } \\
\text { al., 1996; van Meyel et al., 1994; von } \\
\text { Deimling et al., 1992a; Watanabe et } \\
\text { al., 1997; Willert et al., 1995; Wu et } \\
\text { al., 1993; Zhang et al., 1993 }\end{array}$ \\
\hline
\end{tabular}

Yeast assay

p53 Mutation

$0 / 16^{c}(0)$

$22 / 52^{d}(40)$

$10 / 15^{\mathrm{e}}(67)$

$18 / 43^{\mathrm{e}}(42)$

$\mathrm{LOH}$, loss of heterozygosity; WHO, World Health Organization.

${ }^{a}$ Kleihues et al., 1993.

${ }^{\mathrm{b}}$ Number of cases positive/total. Numbers in parentheses are percent of total tumors.

'Ishii et al., 1998.

IIshii, N., Tada, M., and Van Meir, E.G. (1999) Manuscript in preparation.

'Tada et al., 1997. 
Table 2. p53 mutation in nonastrocytic lineage gliomas

\begin{tabular}{lccl} 
Tumor & No. cases positive/total & p53 mutation frequency (\%) & \multicolumn{1}{c}{ References } \\
\hline $\begin{array}{l}\text { Oligoastrocytoma } \\
\text { Oligodendroglioma }\end{array}$ & $12 / 32$ & 32 & Maintz et al., 1997 \\
Ependymoma & & $0-5$ & $\begin{array}{l}\text { Maintz et al., 1997; J. Reifenberger et al., } \\
1994\end{array}$ \\
& $1 / 74$ & 1 & $\begin{array}{l}\text { Fink et al., 1996; Hsieh et al., 1994; Metzger } \\
\text { et al., 1991; Nozaki et al., 1998; Ohgaki et al., } \\
\text { PNET/medulloblastoma }\end{array}$ \\
& $5 / 81$ & 6 & $\begin{array}{l}\text { 1991 } \\
\text { Adesina et al., 1994; Badiali et al., 1993; } \\
\text { Hsieh et al., 1994; Ohgaki et al., 1993; } \\
\text { Reifenberger et al., 1996; Saylors et al., 1991; } \\
\text { Tsumanuma et al., 1995; Wu et al., 1993 }\end{array}$ \\
\hline
\end{tabular}

may conclude that $p 53$ mutation is not relevant to tumorigenesis of pilocytic astrocytomas, making it an entity genetically distinct from the grade II-IV spectrum.

In contrast, p53 mutations were detected in considerable fractions of higher-grade astrocytic tumors, indicating that loss of p53 function plays an important role in tumorigenesis of subsets of these tumors. It is particularly interesting that anaplastic astrocytomas showed the highest prevalence $(67 \%)$ of p53 mutation (Tada et al., 1997). This is also apparent in the previously documented mutations in anaplastic astrocytomas $(30 \%$; Table 1). This counterintuitive phenomenon that the less malignant anaplastic astrocytomas show a higher mutation rate than more malignant glioblastomas is explainable if we consider dual pathways of malignant progression to glioblastoma: one pathway where low-grade astrocytoma progresses to glioblastoma by expansion of mutated p53 cells and another where glioblastoma occurs de novo without p53 mutations.

Table 2 shows a collective summary of reported p53 mutations in nonastrocytic glial tumors. Ependymomas and primitive neuroectodermal tumors/medulloblastomas only rarely display p53 mutations, even though they often contain an astrocytic component (Nozaki et al., 1998; Saylors et al., 1991). Although pure oligodendrogliomas rarely harbor mutant $p 53$ genes, one-third of the cases of mixed oligoastrocytoma show aberrant $p 53$ genes (Maintz et al., 1997; Reifenberger et al., 1996). It is interesting that the other two-thirds display allelic loss of chromosomes $1 \mathrm{p}$ and $19 \mathrm{q}$, which is often seen in pure oligodendroglioma (Maintz et al., 1997), suggesting that oligoastrocytoma might originate through a transformation in either the astrocytic lineage due to p53 mutations or the oligodendrocytic lineage without involvement of p53 mutation.

\section{Consequences of p53 Functional Loss due to Mutation/Allelic Loss}

Loss of $G_{1}$ Check Point and DNA Repair: Uninhibited Growth and Genetic Instability

p53 arrests cells possessing DNA damage in the $G_{1}$ phase of the cell cycle and promotes the cellular mechanisms of DNA repair. These functions are accomplished by transcriptional activation of $\mathrm{CDK}^{3}$ inhibitor p21/CDKN1, and a set of mismatch repair genes, such as human mutS homologue-2 (hMSH2) (Scherer et al., 1996), growth arrest DNA damage inducible-45
(GADD45) (Carrier et al., 1994; Hollander et al., 1993), and PCNA (proliferating-cell nuclear antigen; cofactor of DNA polymerase $\delta$ and $\varepsilon$ ) (Morris et al., 1996). In addition, p53 controls centrosome formation in the M-phase (Fukasawa et al., 1996). Loss of these p53 functions through mutation and allelic loss results in uninhibited cellular growth, genetic instability, and malignant transformation of the cells (Agapova et al., 1996; Liu et al., 1996).

\section{Loss of Apoptosis: Immortalization}

p53 transactivates the gene encoding pro-apoptotic factor, Bax, which triggers apoptosis (Miyashita and Reed, 1995) and represses the transcription of the $\mathrm{Bcl}-2$ gene whose product suppresses apoptosis (Miyashita et al., 1994). $\mathrm{Bcl}-2$ is present on the mitochondrial outer membrane and tethers CED-4/caspase 3 complexes, which are released in the presence of Bax by competitive binding to the binding-site of CED-4. Bax also creates "megapores" on the mitochondrial membranes by a notyet-defined mechanism that leads to "permeability transition" of the membrane and release of apoptosis-inducing factors (AIF) such as cytochrome c (Kroemer, 1997; Reed, 1997). The released caspase 3, also called CPP32, is further activated by caspase 1 (interleukin- $1 \beta$ converting enzyme; ICE), which in turn is activated by a cytochrome c-mediated process, cleaves PARP (poly(ADP) ribose polymerase), and thereby initiates an apoptotic cascade reaction (Kluck et al., 1997; H. Li et al., 1997). Caspase 3 also cleaves Bcl-2 into a Bax-like pro-apoptotic factor, enhancing the mitochondrial change (Fig. 1.) (Cheng et al., 1997).

The activation of $\mathrm{p} 53$, however, does not always induce this apoptotic process; there is a selection between $\mathrm{G}_{1}$ arrest and apoptosis, depending on cell-type and condition (Polyak et al., 1996). p21/CDKN1 and RB (retinoblastoma susceptibility) proteins have recently been considered to mediate the selection. For apoptosis, the $\mathrm{Rb}$ protein is dephosphorylated by a serine/threonine phosphatase and cleaved into two proteins, $\mathrm{p} 48$ and p68, by a caspase-like protease (Fattman et al., 1997; Fu et al., 1998). p48 remains in the cytosol, while p68 moves into the nucleus where it abrogates transcriptional activity of E2F without binding to it. Since transcriptional repression mediates the apoptosis induced by E2F overexpression (Hsieh et al., 1997), it is conceivable that the liberated E2F, which lacks transactivation competence but retains transcriptional repressive activity, grants permis- 


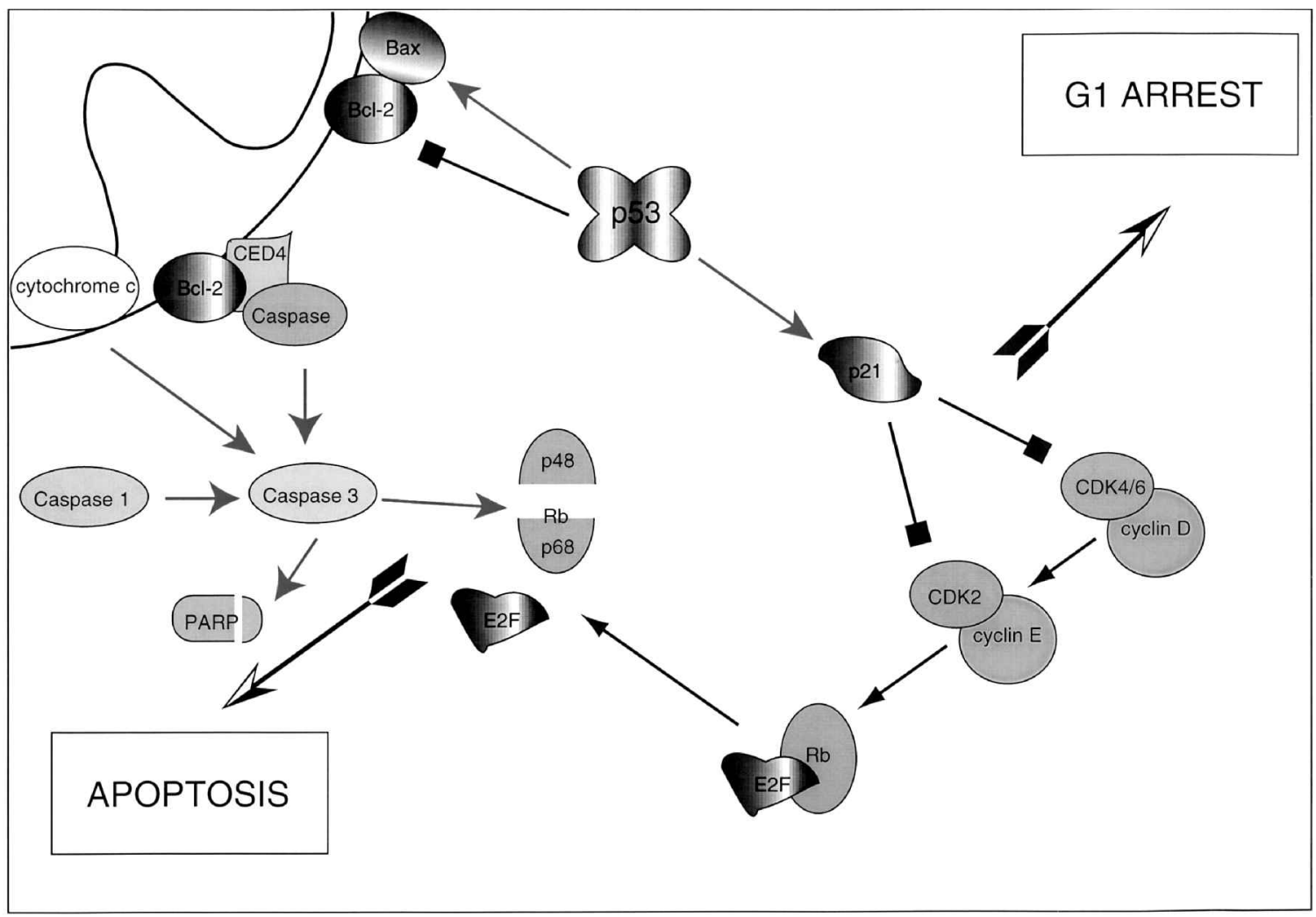

Fig. 1. Two response pathways, apoptosis (left side) and $\mathrm{G}_{1}$ block (right side), after p53 activation. Induction of Bax causes mitochondrial reactions leading to caspase release and membrane permeability changes and initiates apoptosis. In glioma cells, however, p21 induction is the predominant effect consequently suppressing apoptosis.

sion to proceed with apoptosis. By preventing cell cycle progression to the late $G_{1}$ phase, during which E2F is synthesized, p21 may prevent this permission of E2F (Fig. 1) (Hsieh et al., 1997; Waldman et al., 1997).

Loss of p53 function results in lack of p53-dependent apoptosis, conferring resistance to DNA damaging agents. On the other hand, however, retention of wildtype $\mathrm{p} 53$ function does not warrant better sensitivity to DNA damaging agents in certain tumor cells (Kondo et al., 1996), particularly in glioblastoma cells, as discussed later. Predominant induction of p21 compared with Bax, in fact makes $G_{1}$ arrest a preferred event over Rb cleavage and apoptosis in glioblastoma cells (Jung et al., 1995; Wagenknecht et al., 1997).

\section{Loss of Gene Regulatory Function and "Gain of Function"}

Other genes that are transactivated by $\mathrm{p} 53$ include MDM2 (murine double-minute 2) (Barak et al., 1993), EGFR (epidermal growth factor receptor) (Deb et al., 1994; Ludes Meyers et al., 1996), TGF- $\alpha$ (transforming growth factor- $\alpha$ ) (Shin et al., 1995), $D D R$ (discoidin domain receptor) (Sakuma et al., 1996), IGF-BP3 (insulin-like growth factor binding protein 3) (Buckbinder et al., 1995), cyclin G (Okamoto and Beach, 1994), and A28-RGS14 (G-protein regulator) (Buckbinder et al., 1997). In addition to its function as a specific transcriptional activator, p53 is known to act as a transcriptional repressor for genes with TATA and CAAT boxes in their promoter sequence (Agoff et al., 1993; Mack et al., 1993; Ragimov et al., 1993). The repressed genes include cyclin A (Desdouets et al., 1996), IGFII (Zhang et al., 1996), IGFI receptor (Werner et al., 1996), VEGF (vascular endothelial growth factor) (Mukhopadhyay et al., 1995), bFGF (basic fibroblast growth factor) (Ueba et al., 1994), interleukin 6 (Margulies and Sehgal, 1993; Santhanam et al., 1991), MDR1 (multiple drug resistance 1) (Zastawny et al., 1993), MGMT $\left(O^{6}\right.$ methylguanine methyl transferase) (Harris et al., 1996), $i$ NOS (inducible nitric oxide synthase) (Forrester et al., 1996), c-fos (Ginsberg et al., 1991), c-jun (Kieser et al., 1994), hsc70 (heat shock cognate protein 70) (Ginsberg et al., 1991), and $h s p 70$ (heat shock protein 70) (Agoff et al., 1993). Thus, loss of p53 function may cause derepression (or release from repression) of these genes, leading to augmented expression of autocrine growth factors and their receptors, paracrine angiogenic cytokines, drug resistant genes, and growth-promoting oncogenes.

Furthermore, certain p 53 mutants, such as $175 \mathrm{H}$ and 248Q, paradoxically up-regulate transcription of several genes, including IGFI receptor (Werner et al., 1996), EGFR (Ludes Meyers et al., 1996), VEGF (Kieser et al., 1994), IL6 (Santhanam et al., 1991), and MDR1 (Zastawny et al., 1993). These effects could be explained by dominant negative action of mutant $\mathrm{p} 53$ on the repressive activity of wild-type p53 in heterozygous cells. However, when transfected into p53 null cells, mutants 
Table 3. Characteristics of the two subsets of adult cerebral glioblastomas

\begin{tabular}{|c|c|c|c|}
\hline Characteristic & Type 1, progressed, secondary ${ }^{a}$ & Type 2, de novo, primary ${ }^{\mathrm{a}}$ & References \\
\hline Age of onset & Young age; mean 42 & Older age; mean 55-60 & Leenstra et al., 1994; Tada et al., 1998 \\
\hline Prognosis & Poor & Extremely poor & Leenstra et al., 1994; Tada et al., 1998 \\
\hline p53 Mutation & Positive & Negative & $\begin{array}{l}\text { Lang et al., 1994a; von Deimling et al., } \\
\text { 1993; Watanabe et al., } 1996\end{array}$ \\
\hline EGFR gene amplification & Infrequent & Frequent & $\begin{array}{l}\text { Lang et al., 1994a; von Deimling et al., } \\
\text { 1993; Watanabe et al., } 1996\end{array}$ \\
\hline p16 Gene deletion & Infrequent (4) & Frequent (36) & $\begin{array}{l}\text { Biernat et al., 1997a, 1997b; Hayashi et } \\
\text { al., 1997; Hegi et al., 1997; Lang et al., } \\
\text { 1994a; Ono et al., } 1996\end{array}$ \\
\hline PTEN loss & Infrequent (4) & Frequent (20-40) & $\begin{array}{l}\text { Liu et al., 1997; Rasheed et al., 1997; } \\
\text { Tohma et al., } 1998\end{array}$ \\
\hline 10q Loss & Equally frequent (70) & $\begin{array}{l}\text { Equally frequent or } \\
\text { more frequent (70-90) }\end{array}$ & $\begin{array}{l}\text { Lang et al., 1994a; Leenstra et al., } \\
\text { 1994; Rasheed et al., 1994, 1997; Schlege } \\
\text { et al., 1996; von Deimling et al., 1992b, } \\
1993\end{array}$ \\
\hline CDK4 amplification & Some (23) & Rare (4) & $\begin{array}{l}\text { Biernat et al., 1997b; Meyer-Puttlitz et al., } \\
\text { 1997; Mukhopadhyay et al., 1995; } \\
\text { Rasheed et al., } 1997\end{array}$ \\
\hline RB loss & Relatively frequent (23) & Some (14) & $\begin{array}{l}\text { Biernat et al., 1997; Ichimura et al., 1996; } \\
\text { Schlegel et al., 1996; Tsuzuki et al., 1996; } \\
\text { Ueki et al., } 1996\end{array}$ \\
\hline
\end{tabular}

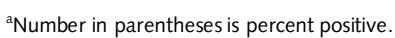

can confer dominant oncogenic properties, such as an increased tumorigenicity, suggesting a gain of function (Elledge and Lee, 1995).

\section{p53 Mutation and Prognosis of Glioma Patients}

Two Subsets of Glioblastoma Multiforme: Malignant

Progression from Low-Grade Astrocytomas or

De Novo Glioblastomas

It has recently been proposed that adult cerebral glioblastomas comprise at least two subsets that are clinically and genetically distinct. Type 1 denotes the secondary glioblastoma, which is considered to have undergone stepwise malignant progression from low-grade astrocytoma and is marked by loss of p53 function (Sidransky et al., 1992; Tada et al., 1996). Type 2 represents the de novo or primary glioblastoma, which occurs without a preceding lesion, has intact p53 function, but shows amplification of the EGFR gene (Leenstra et al., 1994). Table 3 shows characteristics of the two glioblastoma subsets drawn from recent literature. Clinically, type 1 affects relatively younger patients and shows somewhat longer survival, whereas type 2 occurs in elderly patients and is associated with shorter survival (Leenstra et al., 1994; von Deimling et al., 1993). Using conventional techniques (i.e., SSCP) for detecting p53 mutations, the difference in survival between the two subsets has remained unclear, but using a yeast p53 functional assay, a significant difference in survival between groups of patients with or without the $p 53$ gene mutation was found (Tada et al., 1998). Adult patients with cerebral glioblastoma survived $14.2 \pm 1.7$ months when p 53 was wild-type and $29.7 \pm 3.3$ when p53 was mutated $(P<0.0003)$. Surprisingly, the difference in survival times between the two groups appeared due mainly to a difference in the period of tumor growth control after radiation (regrowth-free period). Survival time after regrowth was independent of p53 status, suggesting that the difference in survival was related to the treatment rather than the intrinsic aggressiveness of the tumor (Tada et al., 1998). Because of the small number of tumors (36) analyzed in this study, it will be important to confirm them in a larger patient series.

This observation contrasts with the well-accepted hypothesis that p53 inactivation is associated with decreased radiosensitivity due to abrogated p53-dependent apoptosis (Clarke et al., 1993; Lowe et al., 1993). As mentioned before, however, when p21 is the predominant factor induced by $\mathrm{p} 53$ rather than the pro-apoptotic factors, the consequent $G_{1}$ arrest blocks the cell cycle progression necessary for p53-dependent apoptosis, resulting in a decreased sensitivity to DNA-damaging agents (Yount et al., 1996). It is also possible that glioblastoma without p53 mutation harbors another genetic defect elsewhere that causes radioresistance. In glioblastoma cells with p53 mutations, radiation does not block cell cycle progression, thus allowing $G_{2} M-$ related p53-independent apoptosis to occur (Allday et al., 1995; Hsieh et al., 1997; Strasser et al., 1994). Similar associations of p53 mutation with higher sensitivity to DNA-damaging agents have been reported in other types of cancers (Cote et al., 1997; Fan et al., 1995; Wahl et al., 1996).

\section{Malignant Progression from Low-Grade Astrocytoma}

Although p53 inactivation plays an important role in astrocytoma progression, it is not the sole factor determining the progression, since almost all low-grade astrocytomas recur within 5-15 years after initial surgical 
Table 4. Other genetic abnormalities found in astrocytic tumors

\begin{tabular}{|c|c|c|c|c|}
\hline Gene abnormality & Astrocytoma (\%) & $\begin{array}{c}\text { Anaplastic } \\
\text { astrocytoma (\%) }\end{array}$ & $\begin{array}{l}\text { Glioblastoma } \\
\text { multiforme (\%) }\end{array}$ & References \\
\hline $\mathrm{G}_{1}$ checkpoint regulators & & Total 66 & Total $>90$ & $\begin{array}{l}\text { Adnane, 1995; Arap et al., 1995; } \\
\text { G. Reifenberger et al., 1994; Ichimura et al., } \\
\text { 1996; Jen et al., 1994; Moulton et al., 1995; } \\
\text { Rasheed et al., 1997; Schmidt et al., 1997; } \\
\text { Tenan et al., 1995; Ueki et al., } 1996\end{array}$ \\
\hline p16/INK4A loss & 0 & 20 & $40-68$ & \\
\hline p15/INK4B loss & 0 & 20 & $22-68$ & \\
\hline RB1 loss & 0 & 25 & $14-33$ & \\
\hline CDK4/6 amplification & & $8-17$ & $12-14$ & \\
\hline p53-Interactive protein & & & & G. Reifenberger et al., 1994 \\
\hline mdm2 Amplification & 0 & 10 & 10 & \\
\hline Receptor tyrosine kinase & & & & Diedrich et al., 1995; Hurtt et al., 1992 \\
\hline EGFR amplification & $25-33$ & $33-50$ & $32-68$ & \\
\hline Chromosome $10 \mathrm{q}$ genes & & & Total $>90$ & Albarosa et al., 1996; Chiariello et al., 1998; \\
\hline PTEN/MMAC1 loss & 0 & Mutation 23 & $\begin{array}{l}\text { Mutation 31-44 } \\
\quad(\mathrm{LOH} 75)\end{array}$ & $\begin{array}{l}\text { Karlbom et al., 1993; Lang et al., 1994a; } \\
\text { Mollenhauer et al., 1997; Nakamura et al., }\end{array}$ \\
\hline DMBT-1 loss ${ }^{\mathrm{a}}$ & & & Deletion 23 & 1998; Rasheed et al., 1995, 1997; Schlegel \\
\hline h-neuralized loss ${ }^{\mathrm{a}}$ & - & ${ }^{\mathrm{b}}$ Deletion 33 & ${ }^{\mathrm{b}}$ Deletion 50 & et al., 1996; Wang et al., 1997 \\
\hline \multicolumn{5}{|l|}{ Chromosome 17p13.3 } \\
\hline Regional LOH & 5 & 67 & 40 & Chattopadhyay et al., 1997; Rasheed et al., 1995 \\
\hline
\end{tabular}

removal, and $80 \%$ of these are associated with malignant progression (Kraus et al., 1994; Muller et al., 1977). Loss of other tumor suppressor genes, such as $P T E N$ and $R B$, appear essential for malignant progression of astrocytomas in the absence of p53 mutation. Van Meyel et al. (1994) observed that progression of a grade 2 astrocytoma into an anaplastic astrocytoma occurs frequently with p53 mutation, but direct progression into a glioblastoma does not, indicating another pathway of malignant progression not requiring p53 mutation (van Meyel et al., 1994).

MDM2 gene amplification and overexpression are seen in about $10 \%$ of high-grade astrocytomas but in none of grade II astrocytomas (Costanzi-Strauss et al., 1998). The Mdm2 protein opposes the functions of $\mathrm{p} 53$ directly by inhibiting its transcriptional activity and promoting its degradation (Chen et al., 1996; Haupt et al., 1996, 1997; Momand et al., 1992; G. Reifenberger et al., 1994) and indirectly by interacting with E2F1 and $\mathrm{Rb}$ family proteins, p107 and Rb1 (Dubs-Poterszman et al., 1995; Haupt et al., 1997; Kubbutat et al., 1997; Martin et al., 1995; Xiao et al., 1995). MDM2 amplification is thus considered to replace p53 inactivation in the astrocytic tumors without p53 mutation. Moreover, we have recently shown that the presence of short alternative transcript forms of MDM2 is highly correlated with malignancy of astrocytic tumors (Matsumoto et al., 1998). Since the short alternative transcript products do not contain the p53 binding domain, they may carry oncogenic functions rather than interfering with the p53 protein.

\section{Abnormality of Other Genes as Alternatives to the p53 Inactivation Pathway}

p53 inactivation causes a set of tumor phenotypes essential for glioma development, including uninhibited growth, genetic instability, suppressed apoptotic cell death (immortalization), and altered gene expression that supports tumor growth. This immediately raises the question of what gene abnormalities would replace p53 mutations in wild-type p53 gliomas, which are histologically indistinguishable from mutant p53-harboring glioblastomas (Table 4).

\section{EGFR Amplification and PTEN/MMAC1 Loss}

Amplification of the EGFR gene on chromosome 7 is seen in about $40 \%$ of glioblastomas. It is mostly associated with the retention of the wild-type $p 53$ gene, forming a distinct genetic subset (Lang et al., 1994a, Leenstra et al., 1994; Rasheed et al., 1994, 1997; Tada et al., 1998). While it is generally thought to be seen exclusively in grade IV tumors (Ekstrand et al., 1991; Lang et al., 1994a, von Deimling et al., 1992b), some authors have also reported it in lower-grade astrocytomas (Diedrich et al., 1995; Hurtt et al., 1992). The amplified EGFR gene, in combination with coexpressed $T G F \alpha$, forms an autocrine loop that transduces signals via MAP (mitogen-activated protein) kinase, STAT (signal transducer and activator of transduction), and PLC (phospholipase C)- $\gamma$ (Tang et al., 1997), leading to the activation of cyclin D/CDK4/6 complexes. Moreover, $40-50 \%$ of the amplified EGFR genes 
are rearranged (i.e., lack exons 2 to 7; extracellular domain), encoding a truncated receptor that transduces continuous signals in the absence of the ligand (Ekstrand et al., 1992; Nishikawa et al., 1994). The EGFR gene amplification promotes not only cellular growth but also invasiveness of glioma cells, as evidenced by the inhibition of cell invasiveness by tyrphostin A25, a specific inhibitor of the EGFR tyrosine kinase (Penar et al., 1997).

PTEN/MMAC1 gene on chromosome 10q23.3 was identified as a tumor suppressor gene that is deleted and/or mutated in glioblastomas, prostate cancers, breast cancers, and kidney cancers (J. Li et al., 1997; Steck et al., 1997). Subsequently, constitutive mutations were found in Cowden disease, juvenile polyposis coli, and Bannayan-Zonana's syndrome (Liaw et al., 1997; Marsh et al., 1997; Olschwang et al., 1998). Somatic mutation of the PTEN/MMAC1 gene is found in about $30 \%$ of glioblastomas (Boström et al., 1998; Chiariello et al., 1998; Liu et al., 1997; Teng et al., 1997; Wang et al., 1997), but it is generally absent in low-grade astrocytomas (Rasheed et al., 1997), suggesting that PTEN/MMAC1 plays a role in the final step of astrocytoma progression. However, although loss of heterozygosity on chromosome $10 \mathrm{q}$ is found in about $70 \%$ of glioblastomas, complete loss of PTEN/MMAC1 alleles by mutation of the second allele accounts for only a fraction of these (Boström et al., 1998; Wang et al., 1997). Introduction of wild-type PTEN into glioma cells containing endogenous mutant alleles causes growth suppression, but has no effect in cells containing endogenous wild-type PTEN, suggesting that only bi-allelic loss of the PTEN gene by loss of heterozygosity plus mutation causes inactivation of the PTEN tumor suppressor function (Furnari et al., 1997). Taking this into account, along with the notion that there are at least three targeted loci $(10 \mathrm{p} 14$ $\mathrm{p} 15,10 \mathrm{q} 23$, and 10q24-q26) for chromosome 10 loss in glioblastomas (Karlbom et al., 1993), it is likely that other genes are also involved in the progression to glioblastomas. Two such candidate tumor suppressor genes have been discovered: One is DMBT1 at 10q25.3-q26.1 (Mollenhauer et al., 1997) and the other is human neuralized at 10q25.1 (Nakamura et al., 1998). Although chromosome 10 loss is more frequently seen in glioblastomas with EGFR gene amplification (Lang et al., 1994a, Leenstra et al., 1994; Schlegel et al., 1996; von Deimling et al., 1992b, 1993), PTEN mutation is not associated with EGFR gene amplification (Liu et al., 1997).

PTEN is known to act as a dual specificity phosphatase, removing phosphate residues from tyrosines and serines (Myers et al., 1997). Certain tyrosine phosphatases can inhibit the oncogenic activity of protein tyrosine kinase receptors by dephosphorylation (Brown-Shimer et al., 1992; Sorby and Ostman, 1996). Therefore, it is worth investigating whether PTEN gene loss means a loss of the negative feedback mechanism of EGFR signaling.

Introduction of chromosome 10 can restore production of thrombospondin-1 (a potent inhibitor of angiogenesis) in glioma cells (Hsu et al., 1996). This is interesting because endothelial proliferation is the hallmark that distinguishes glioblastoma from anaplastic astrocytoma (Barker et al., 1996), although it is unknown which chromosome 10 gene is responsible for this effect. More recently, it has been shown that the overexpression of PTEN can inhibit cell migration and the antisense suppression of PTEN expression can enhance cell migration (Tamura et al., 1998). This is done partly by down-regulating integrin-mediated cell spreading and partly by abrogating focal adhesion, resulting from dephosphorylation of focal adhesion kinase (FAK). It is thus possible that PTEN gene loss confers invasiveness on the tumor cells, which is characteristically seen in glioblastomas.

\section{p16 Loss, Amplification of CDK4, and RB Loss}

Both $p 16$ (INK4A/CDKN2A) and $p 15$ (INK4B/CDKN2B) on chromosome $9 \mathrm{p} 21$ inhibit $\mathrm{G}_{1}$ cyclin-dependent kinases CDK4 and CDK6 (Hannon and Beach, 1994; Kamb et al., 1994; Serrano et al., 1993). They bind to the CDK and inhibit phosphorylation by CAK (CDK-activating kinase). Together with recently discovered $p 18$ and $p 19$ genes on chromosome 19p13, they constitute the INK4 family (Chan et al., 1995; Guan et al., 1994; Hirai et al., 1995). Homozygous deletion of the $p 16$ gene is found in about $40 \%$ of glioblastomas (Brown-Shimer et al., 1992; Myers et al., 1997). Although there is disagreement over whether 0\% (Izumoto et al., 1995; Moulton et al., 1995) or 20\% (Schmidt et al., 1994; Uhrbom et al., 1997) of anaplastic astrocytomas display p16 loss, there is general consensus that the loss is not present in grade II astrocytomas, suggesting that p16 loss is associated with later stages of astrocytoma tumorigenesis/progression. On the other hand, homozygous deletions of the $p 15$ gene occur only in $13 \%$ of glioblastomas (Izumoto et al., 1995), suggesting that p16 is the main target of chromosome 9p21 deletion in glioblastomas. Most p16 inactivations in glioblastomas consist of homozygous deletions; point mutations are uncommon (Kyritsis et al., 1996). In other types of human cancers, hypermethylation of the p16 promoter accounts for $20 \%$ of causes of p16 inactivation, but it is infrequent in gliomas (Schmidt et al., 1997).

Quite interestingly, p16 loss is often associated with EGFR gene amplification (Hayashi et al., 1997; Hegi et al., 1997). In addition, glioblastomas without p16 loss often display CDK4 or CDK6 amplification and/or $R B$ gene mutation (Costello et al., 1997; Ichimura et al., 1996; Schmidt et al., 1997; Sonoda et al., 1995; Ueki et al., 1996). Because CDK4/6 are the final targets of EGFR signal transduction, amplification of the target genes may cooperate with the augmented EGFR signal. p16 introduction in glioma cells reduces cellular growth (Arap et al., 1995). The functional significance of p16 deletion is not restricted to the influence on cellular growth; inhibition of apoptosis is also implicated by lines of evidence that simultaneous expression of $p 16$ and $p 53$ induces apoptosis in tumor cells (Sandig et al., 1997), that p16 introduction reverts immortalization in glioma cells (Uhrbom et al., 1997), and that p16 can enhance the radiation sensitivity of glioma cells (Miyakoshi et al., 1997). Since apoptosis by p16 overexpression in tumor cells requires the presence of the $\mathrm{Rb}$ protein (Costanzi-Strauss et al., 1998), it is likely that the above-mentioned decision of apoptosis by $\mathrm{Rb}-\mathrm{E} 2 \mathrm{~F}$ is involved in this process, although this remains to be clarified. 


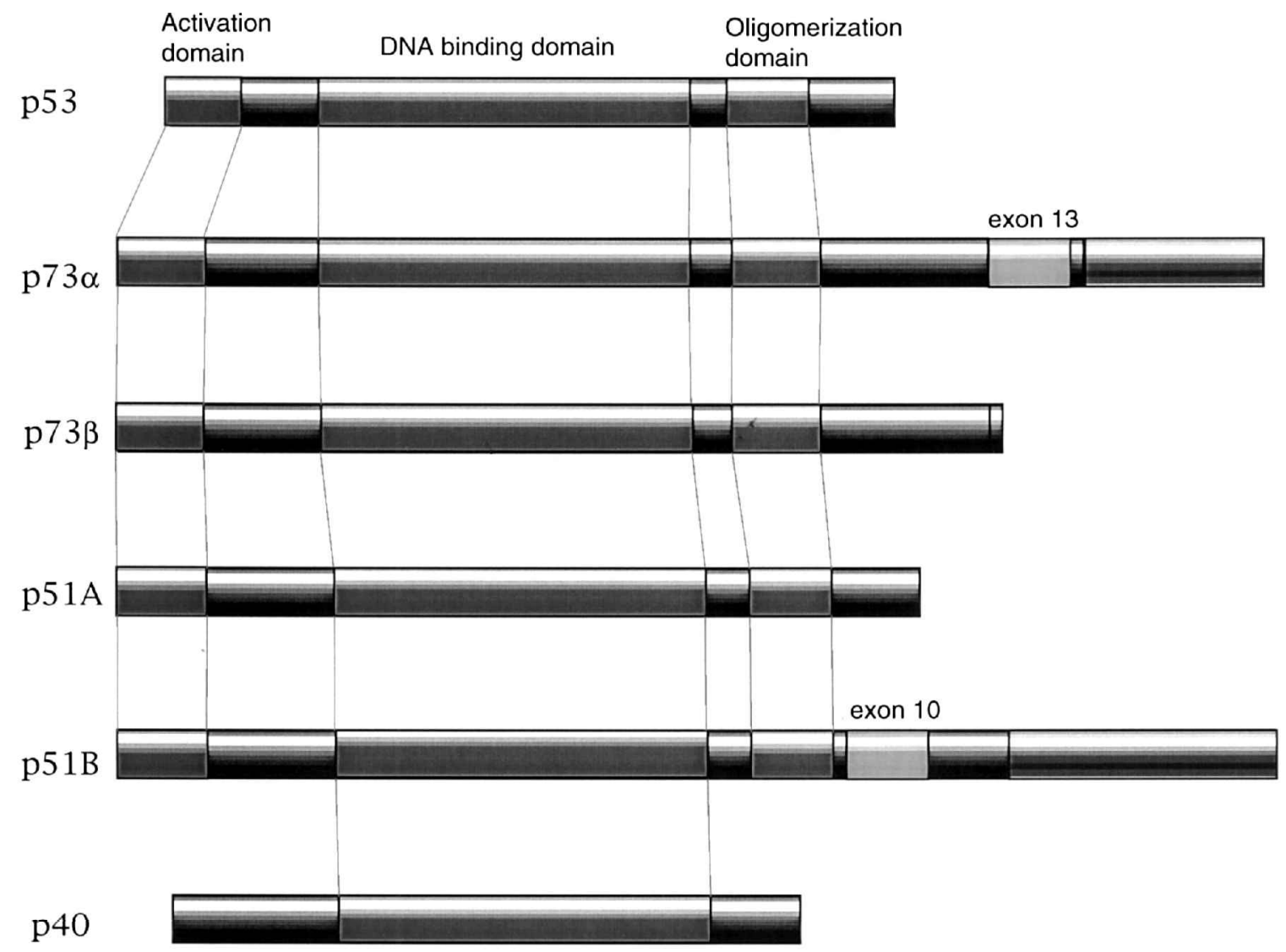

100 amino acids

Fig. 2. Structure of the new putative tumor suppressors $p 73, p 51$, and $p 40$, which are homologous to $p 53$. In $p 73$, alternative splicing gives two isoforms, $p 73 \alpha$ (636 amino acids) and $p 73 \beta$ (499 amino acids). $\beta$ type is predominantly expressed in brain tumors. Similarly, $p 51$ has two isoforms, p51A (448 amino acids) and p51B (641 amino acids).

\section{Three New Putative Tumor Suppressors Homologous to p53}

Three new genes that are homologous to the $p 53$ gene have been discovered successively in recent times (Jost et al., 1997; Kaghad et al., 1997; Osada et al., 1998; Trink et al., 1998). According to their molecular weights, they are $p 73$ (in two forms), $p 51$, and $p 40$, comprising four members of the $p 53$ family.

\section{p73 Gene}

The p73 gene has recently been identified in the chromosome $1 \mathrm{p} 36$ region, which is frequently deleted in pediatric neuroblastomas (Jost et al., 1997; Kaghad et al., 1997). Two alternative splice forms are known: p $73 \alpha$, which is composed of 636 amino acids, and p73 $\beta$, which terminates at 499 amino acids due to a frameshifting splice-out of exon 13 (Kaghad et al., 1997). The 420 amino acids on the $\mathrm{N}$-terminal side make up the region homologous to $\mathrm{p} 53$, which contains a transactivation domain, a DNA-binding domain, and an oligomerization domain; functions of the remaining 610 amino acids for $\mathrm{p} 73 \alpha$ and 80 amino acids for $\mathrm{p} 73 \beta$ are completely unknown (Fig. 2). In contrast to the quite high homology of the DNA-binding domain, the transactivation domain of p73 shares relatively fewer sequences; p73 transcription is not activated by DNAdamaging agents such as actinomycin $\mathrm{D}$ and ionizing radiation. However, there is an MDM2 binding sequence in the domain, suggesting that p73 is also under negative control by MDM2, as is p53. In vitro p73 is able to perform many functions associated with the tumor suppressor function of $\mathrm{p} 53$; growth arrest, apoptosis, and transactivation. Although chromosome $1 \mathrm{p} 36$ loss has been described in a wide variety of human tumors including oligodendrogliomas and oligoastrocytomas (Maintz et al., 1997; Schiffer et al., 1995; Sure et al., 1997), mutation in the $p 73$ gene has not been found in several studies so far (Bello et al., 1994; Kraus et al., 1995; Mai et al., 1998; Nomoto et al., 1998; Sunahara et al., 1998; Takahashi et al., 1998). Since losses of heterozygosity on $17 \mathrm{p} 13.1$ and $1 \mathrm{p} 36$ are not generally associated, $\mathrm{p} 73$ does not appear sufficient to compensate for loss of p53 function. 


\section{p51 and $p 40$ Genes}

Two additional members of the p53 family-the $p 51$ and the $p 40$ genes-have been identified by different groups using degenerated primers and polymerase chain reaction (Osada et al., 1998; Trink et al., 1998). In the DNA-binding domains, $p 51$ and $p 40$ are 60 and $55 \%$, respectively, homologous to $p 53$, and 85 and $87 \%$, respectively, homologous to $p 73$. As a whole, $p 51$ and $p 40$ appear more similar to $p 73$ than to $p 53$. Both $p 51$ and $p 40$ genes are located on the telomeric portion of chromosomal arm 3q. The $p 51$ gene produces two alternative splice isoforms, $\mathrm{p} 51 \mathrm{~A}(50.9 \mathrm{kDa})$ and $\mathrm{p} 51 \mathrm{~B}(71.9$ $\mathrm{kDa}$ ), the former lacking exon 10 as $\mathrm{p} 73 \beta$ lacks exon 13 (Fig. 2). p51B is expressed in various organs but not in brain; p $51 \mathrm{~A}$ is specifically expressed in skeletal muscles. p40 is peculiar among the p53 family because it seems to lack an oligomerization domain (Fig. 2). It is possible that $\mathrm{p} 40$ is identical to the $\mathrm{p} 53$ competing protein (p53CP), which was recently isolated by another group (Bian and Sun, 1997). If it is, p40 might be a regulator of the p53 pathway by competing with p53 binding to DNA.

\section{Concluding Remarks}

Many attempts have failed to make a breakthrough in therapy for patients with malignant astrocytic tumors over the past two decades. Theories on which these past "innovative" therapies depended may have depended on a too-simple understanding of the characteristics of malignant gliomas. Recent molecular genetic studies have at least made it very clear that the disease is far more complex than previously thought. Methods are now available to stratify glioblastoma cases into at least two subsets, which are histologically indistinguishable but may respond differently to radio- and/or chemotherapies. In the near future, information on the status of several genes in a tumor will be essential to determine the most appropriate set of therapeutic agents and to evaluate the success of clinical trials. In this context, functional reconstitution of defective genes, by either gene therapy or chemical targeting of the related proteins, should be used in combination with conventional agents rather than alone. Efforts, therefore, should be continued to unveil genetic abnormalities and to relate them functionally to respond to therapeutic agents.

\section{References}

Adesina, A.M., Nalbantoglu, J., and Cavenee, W.K. (1994) p53 gene mutation and $\mathrm{mdm} 2$ gene amplification are uncommon in medulloblastoma. Cancer Res. 54, 5649-5651.

Adnane, J., Shao, Z., and Robbins, P.D. (1995) The retinoblastoma susceptibility gene product represses transcription when directly bound to the promoter. J. Biol. Chem. 270, 8837-8843.

Agapova, L.S., llyinskaya, G.V., Turovets, N.A., Ivanov, A.V., Chumakov, P.M., and Kopnin, B.P. (1996) Chromosome changes caused by alterations of p53 expression. Mutat. Res. 354, 129-138.

Agoff, S. N., Hou, J., Linzer, D. I., and Wu, B. (1993) Regulation of the human hsp70 promoter by p53. Science 259, 84-87.

Albarosa, R., Colombo, B.M., Roz, L., Magnani, I., Pollo, B., Cirenei, N., Giani, C., Conti, A.M., DiDonato, S., and Finocchiaro, G. (1996) Deletion mapping of gliomas suggest the presence of two small regions for candidate tumor-suppressor genes in a 17-cM interval on chromosome 10q. Am. J. Hum. Genet. 58, 1260-1267.

Allday, M.J., Inman, G.J., Crawford, D.H., and Farrell, P.J. (1995) DNA damage in human $B$ cells can induce apoptosis, proceeding from $\mathrm{G} 1 / \mathrm{S}$ when p53 is transactivation competent and G2/M when it is transactivation defective. EMBO J. 14, 4994-5005.

Arap, W., Nishikawa, R., Furnari, F.B., Cavenee, W.K., and Huang, H.J. (1995) Replacement of the p16/CDKN2 gene suppresses human glioma cell growth. Cancer Res. 55, 1351-1354.

Badiali, M., Iolascon, A., Loda, M., Scheithauer, B.W., Basso, G., Trentini, G.P., and Giangaspero, F. (1993) p53 gene mutations in medulloblastoma. Immunohistochemistry, gel shift analysis, and sequencing. Diagn. Mol. Pathol. 2, 23-28.

Barak, Y., Juven, T., Haffner, R., and Oren, M. (1993) Mdm2 expression is induced by wild type p53 activity. EMBO J. 12, 461-468.

Barker, F.G., II, Davis, R.L., Chang, S.M., and Prados, M.D. (1996) Necrosis as a prognostic factor in glioblastoma multiforme. Cancer 77, 1161-1166.

Bello, M.J., Vaquero, J., de Campos, J.M., Kusak, M.E., Sarasa, J.L., Saez-Castresana, J., Pestana, A., and Rey, J.A. (1994) Molecular analysis of chromosome 1 abnormalities in human gliomas reveals frequent loss of $1 \mathrm{p}$ in oligodendroglial tumors. Int. J. Cancer 57, 172-175.

Bian, J., and Sun, Y. (1997) p53CP, a putative p53 competing protein that specifically binds to the consensus p53 DNA binding sites: A third member of the p53 family? Proc. Natl. Acad. Sci. USA 94, 14753-14758.

Biernat, W., Kleihues, P., Yonekawa, Y., and Ohgaki, H. (1997a) Amplification and overexpression of MDM2 in primary (de novo) glioblastomas. J. Neuropathol. Exp. Neurol. 56, 180-185.

Biernat, W., Tohma, Y., Yonekawa, Y., Kleihues, P., and Ohgaki, H. (1997b) Alterations of cell cycle regulatory genes in primary (de novo) and secondary glioblastomas. Acta Neuropathol. (Berl.) 94, 303-309.

Bögler, O., Huang, H.J., and Cavenee, W.K. (1995) Loss of wild-type p53 bestows a growth advantage on primary cortical astrocytes and facilitates their in vitro transformation. Cancer Res. 55, 2746-2751.

Boström, J., Cobbers, J.M., Wolter, M., Tabatabai, G., Weber, R.G., Lichter, P., Collins, V.P., and Reifenberger, G. (1998) Mutation of the PTEN (MMAC1) tumor suppressor gene in a subset of glioblastomas but not in meningiomas with loss of chromosome arm 10q. Cancer Res. 58, 29-33.

Brown-Shimer, S., Johnson, K.A., Hill, D.E., and Bruskin, A.M. (1992) Effect of protein tyrosine phosphatase $1 \mathrm{~B}$ expression on transformation by the human neu oncogene. Cancer Res. 52, 478-482.

Buckbinder, L., Talbott, R., Velasco-Miguel, S., Takenaka, I., Faha, B., Seizinger, B.R., and Kley, N. (1995) Induction of the growth inhibitor IGFbinding protein 3 by p53. Nature 377, 646-649.

Buckbinder, L., Velasco-Miguel, S., Chen, Y., Xu, N., Talbott, R., Gelbert, L., Gao, J., Seizinger, B.R., Gutkind, J.S., and Kley, N. (1997) The p53 tumor suppressor targets a novel regulator of $\mathrm{G}$ protein signaling. Proc. Natl. Acad. Sci. USA 94, 7868-7872.

Carrier, F., Smith, M.L., Bae, I., Kilpatrick, K.E., Lansing, T.J., Chen, C.Y., Engelstein, M., Friend, S.H., Henner, W.D., and Gilmer, T.M. (1994) Characterization of human GADD45, a p53-regulated protein. J. Biol. Chem. 269, 32672-32677.

Chan, F.K., Zhang, J., Cheng, L., Shapiro, D.N., and Winoto, A. (1995) Identification of human and mouse p19, a novel CDK4 and CDK6 inhibitor with homology to p16INK4. Mol. Cell. Biol. 15, 2682-2688. 
Chattopadhyay, P., Rathore, A., Mathur, M., Sarkar, C., Mahapatra, A. K., and Sinha, S. (1997) Loss of heterozygosity of a locus on 17p13.3, independent of $\mathrm{p} 53$, is associated with higher grades of astrocytic tumours. Oncogene 15, 871-874.

Chen, J., Wu, X., Lin, J., and Levine, A.J. (1996) Mdm-2 inhibits the G1 arrest and apoptosis functions of the p53 tumor suppressor protein. Mol. Cell. Biol. 16, 2445-2452.

Cheng, E.H., Kirsch, D.G., Clem, R.J., Ravi, R., Kastan, M.B., Bedi, A., Ueno, K., and Hardwick, J.M. (1997) Conversion of Bcl-2 to a Bax-like death effector by caspases. Science 278, 1966-1968.

Chiariello, E., Roz, L., Albarosa, R., Magnani, I., and Finocchiaro, G. (1998) PTEN/MMAC1 mutations in primary glioblastomas and short-term cultures of malignant gliomas. Oncogene 16, 541-545.

Chozick, B. S., Weicker, M. E., Pezzullo, J. C., Jackson, C. L., Finkelstein, S. D., Ambler, M. W., Epstein, M. H., and Finch, P. W. (1994) Pattern of mutant p53 expression in human astrocytomas suggests the existence of alternate pathways of tumorigenesis. Cancer 73, 406-415.

Chung, R., Whaley, J., Kley, N., Anderson, K., Louis, D., Menon, A., Hettlich, C., Freiman, R., Hedley Whyte, E. T., and Martuza, R. (1991) p53 gene mutations and $17 \mathrm{p}$ deletions in human astrocytomas. Genes Chromosomes Cancer 3, 323-331.

Clarke, A.R., Purdie, C.A., Harrison, D.J., Morris, R.G., Bird, C.C., Hooper, M.L., and Wyllie, A.H. (1993) Thymocyte apoptosis induced by p53dependent and independent pathways. Nature 362, 849-852.

Costanzi-Strauss, E., Strauss, B.E., Naviaux, R.K., and Haas, M. (1998) Restoration of growth arrest by p16(INK4), p21(WAF1), pRB, and p53 is dependent on the integrity of the endogenous cell-cycle control pathways in human glioblastoma cell lines. Exp. Cell Res. 238, 51-62.

Costello, J.F., Plass, C., Arap, W., Chapman, V.M., Held, W.A., Berger, M.S., Su Huang, H.J., and Cavenee, W.K. (1997) Cyclin-dependent kinase 6 (CDK6) amplification in human gliomas identified using two-dimensional separation of genomic DNA. Cancer Res. 57, 1250-1254.

Cote, R.J., Esrig, D., Groshen, S., Jones, P.A., and Skinner, D.G. (1997) p53 and treatment of bladder cancer. Nature 385, 123-125.

Deb, S.P., Munoz, R.M., Brown, D.R., Subler, M.A., and Deb, S. (1994) Wildtype human $\mathrm{p} 53$ activates the human epidermal growth factor receptor promoter. Oncogene 9, 1341-1349.

Desdouets, C., Ory, C., Matesic, G., Soussi, T., Brechot, C., and Sobczak Thepot, J. (1996) ATF/CREB site mediated transcriptional activation and p53 dependent repression of the cyclin A promoter. FEBS Lett. 385, 34-38.

Diedrich, U., Lucius, J., Baron, E., Behnke, J., Pabst, B., and Zoll, B. (1995) Distribution of epidermal growth factor receptor gene amplification in brain tumours and correlation to prognosis. J. Neurol. 242, 683-688.

Dubs-Poterszman, M.C., Tocque, B., and Wasylyk, B. (1995) MDM2 transformation in the absence of $\mathrm{p} 53$ and abrogation of the $\mathrm{p} 107 \mathrm{G} 1$ cell-cycle arrest. Oncogene 11, 2445-2449.

Ekstrand, A.J., James, C.D., Cavenee, W.K., Seliger, B., Pettersson, R.F., and Collins, V.P. (1991) Genes for epidermal growth factor receptor, transforming growth factor alpha, and epidermal growth factor and their expression in human gliomas in vivo. Cancer Res. 51, 2164-2172.

Ekstrand, A.J., Sugawa, N., James, C.D., and Collins, V.P. (1992) Amplified and rearranged epidermal growth factor receptor genes in human glioblastomas reveal deletion of sequences encoding portions of the $\mathrm{N}$ - and/or Cterminal tails. Proc. Natl. Acad. Sci. USA 89, 4309-4313.

Elledge, R.M., and Lee, W.H. (1995) Life and death by p53. Bioessays 17, 923-930.

Fan, S., Smith, M.L., Rivet, D.J., II, Duba, D., Zhan, Q., Kohn, K.W., Fornace, A.J., Jr., and O'Connor, P.M. (1995) Disruption of p53 function sensitizes breast cancer MCF-7 cells to cisplatin and pentoxifylline. Cancer Res. 55, 1649-1654.

Fattman, C.L., An, B., and Dou, Q.P. (1997) Characterization of interior cleavage of retinoblastoma protein in apoptosis. J. Cell. Biochem. 67,
399-408.

Fink, K.L., Rushing, E.J., Schold, S.C. J., Jr., and Nisen, P.D. (1996) Infrequency of p53 gene mutations in ependymomas. J. Neurooncol. 27, 111-115.

Flaman, J.-M., Frebourg, T., Moreau, V., Charbonnier, F., Martin, C., Chappuis, P., Sappino, A.-P., Limacher, I.-M., Bron, L., Benhattar, J., Tada, M., Van Meir, E.G., Estreicher, A., and Iggo, R.D. (1995) A simple p53 functional assay for screening cell lines, blood, and tumors. Proc. Natl. Acad. Sci. USA 92, 3963-3967.

Forrester, K., Ambs, S., Lupold, S.E., Kapust, R.B., Spillare, E.A., Weinberg, W.C., Felley Bosco, E., Wang, X.W., Geller, D.A., Tzeng, E., Billiar, T.R., and Harris, C.C. (1996) Nitric oxide-induced p53 accumulation and regulation of inducible nitric oxide synthase expression by wild-type p53. Proc. Natl. Acad. Sci. USA 93, 2442-2447.

Frankel, R.H., Bayona, W., Koslow, M., and Newcomb, E.W. (1992) p53 mutations in human malignant gliomas: Comparison of loss of heterozygosity with mutation frequency. Cancer Res. 52, 1427-1433.

Fu, Y.H.F., Nishinaka, T., Yokoyama, K., and Chiu, R. (1998) A retinoblastoma susceptibility gene product, $\mathrm{RB}$, targeting protease is regulated through the cell cycle. FEBS Lett. 421, 89-93.

Fukasawa, K., Choi, T., Kuriyama, R., Rulong, S., and Vande Woude, G.F. (1996) Abnormal centrosome amplification in the absence of $\mathrm{p} 53$. Science 271, 1744-1747.

Fults, D., Brockmeyer, D., Tullous, M.W., Pedone, C.A., and Cawthon, R.M. (1992) p53 mutation and loss of heterozygosity on chromosomes 17 and 10 during human astrocytoma progression. Cancer Res. 52, 674-679.

Furnari, F.B., Lin, H., Huang, H.J. S., and Cavenee, W.K. (1997) Growth suppression of glioma cells by PTEN requires a functional phosphatase catalytic domain. Proc. Natl. Acad. Sci. USA 94, 12479-12484.

Ginsberg, D., Mechta, F., Yaniv, M., and Oren, M. (1991) Wild-type p53 can down-modulate the activity of various promoters. Proc. Natl. Acad. Sci. USA 88, 9979-9983.

Gomez-Manzano, C., Fueyo, J., Kyritsis, A.P., McDonnell, T.J., Steck, P.A., Levin, V.A., and Yung, W.K. (1997) Characterization of p53 and p21 functional interactions in glioma cells en route to apoptosis. J. Natl. Cancer Inst. 89, 1036-1044.

Guan, K.L., Jenkins, C.W., Li, Y., Nichols, M.A., Wu, X., O'Keefe, C.L., Matera, A.G., and Xiong, Y. (1994) Growth suppression by p18, a p16INK4/MTS1- and p14INK4B/MTS2-related CDK6 inhibitor, correlates with wild-type pRb function. Genes Dev. 8, 2939-2952.

Hannon, G.J., and Beach, D. (1994) p15INK4B is a potential effector of TGFbeta-induced cell cycle arrest. Nature 371, 257-261.

Harris, L.C., Remack, J.S., Houghton, P.J. and Brent, T.P. (1996) Wild-type p53 suppresses transcription of the human O6-methylguanine-DNA methyltransferase gene. Cancer Res. 56, 2029-2032.

Haupt, Y., Barak, Y., and Oren, M. (1996) Cell type-specific inhibition of p53mediated apoptosis by mdm2. EMBO J. 15, 1596-1606.

Haupt, Y., Maya, R., Kazaz, A., and Oren, M. (1997) Mdm2 promotes the rapid degradation of p53. Nature 387, 296-299.

Hayashi, Y., Ueki, K., Waha, A., Wiestler, O.D., Louis, D.N., and von Deimling, A. (1997) Association of EGFR gene amplification and CDKN2 (p16/MTS1) gene deletion in glioblastoma multiforme. Brain Pathol. 7, 871-875.

Hegi, M.E., Zur Hausen, A., Ruedi, D., Malin, G., and Kleihues, P. (1997) Hemizygous or homozygous deletion of the chromosomal region containing the p16(INK4a) gene is associated with amplification of the EGF receptor gene in glioblastomas. Int. J. Cancer 73, 57-63.

Hirai, H., Roussel, M.F., Kato, J.Y., Ashmun, R.A., and Sherr, C.J. (1995) Novel INK4 proteins, p19 and p18, are specific inhibitors of the cyclin D-dependent kinases CDK4 and CDK6. Mol. Cell. Biol. 15, 2672-2681.

Hollander, M.C., Alamo, I., Jackman, J., Wang, M.G., McBride, O.W., and Fornace, A.J., Jr. (1993) Analysis of the mammalian gadd45 gene and its response to DNA damage. J. Biol. Chem. 268, 24385-24393.

Hsieh, J.K., Fredersdorf, S., Kouzarides, T., Martin, K., and Lu, X. (1997) E2F1- 
induced apoptosis requires DNA binding but not transactivation and is inhibited by the retinoblastoma protein through direct interaction. Genes Dev. 11, 1840-1852.

Hsieh, L.-L., Hsia, C.-F., Wang, L.-Y., Chen, C.-J,. and Ho, Y.-S. (1994) p53 gene mutations in brain tumors in Taiwan. Cancer Lett. 78, 25-32.

Hsu, S.C., Volpert, O.V., Steck, P.A., Mikkelsen, T., Polverini, P.J., Rao, S., Chou, P., and Bouck, N.P. (1996) Inhibition of angiogenesis in human glioblastomas by chromosome 10 induction of thrombospondin-1. Cancer Res. 56, 5684-5691.

Hunter, S.B., Bandea, C., Swan, D., Abbott, K., and Varma, V.A. (1993) Mutations in the p53 gene in human astrocytomas: Detection by single-strand conformation polymorphism analysis and direct DNA sequencing. Mod. Pathol. 6, 442-445.

Hurtt, M.R., Moossy, J., Donovan-Peluso, M., and Locker, J. (1992) Amplification of epidermal growth factor receptor gene in gliomas: Histopathology and prognosis. J. Neuropathol. Exp. Neurol. 51, 84-90.

Ichimura, K., Schmidt, E.E., Goike, H.M., and Collins, V.P. (1996) Human glioblastomas with no alterations of the CDKN2A (p16INK4A, MTS1) and CDK4 genes have frequent mutations of the retinoblastoma gene. Oncogene 13, 1065-1072.

Ishii, N., Sawamura, Y., Tada, M., Daub, D.M., Janzer, R.C., Meagher-Villemure, M., de Tribolet, N., and Van Meir, E.G. (1998) Absence of p53 gene mutations in a tumor panel representative of pilocytic astrocytoma diversity using a p53 functional assay. Int. J. Cancer 76, 797-800.

Izumoto, S., Arita, N., Ohnishi, T., Hiraga, S., Taki, T., and Hayakawa, T. (1995) Homozygous deletions of p16INK4A/MTS1 and p15INK4B/MTS2 genes in glioma cells and primary glioma tissues. Cancer Lett. 97, 241-247.

Jen, J., Harper, J.W., Bigner, S.H., Bigner, D.D., Papadopoulos, N., Markowitz, S., Willson, J.K., Kinzler, K.W., and Vogelstein, B. (1994) Deletion of p16 and p15 genes in brain tumors. Cancer Res. 54, 6353-6358.

Jost, C.A., Marin, M.C., and Kaelin, W.G., Jr. (1997) p73 is a human p53related protein that can induce apoptosis. Nature 389, 191-194.

Jung, J.M., Bruner, J.M., Ruan, S., Langford, L.A., Kyritsis, A.P., Kobayashi, T., Levin, V.A., and Zhang, W. (1995) Increased levels of p21WAF1/Cip1 in human brain tumors. Oncogene 11, 2021-2028.

Kaghad, M., Bonnet, H., Yang, A., Creancier, L., Biscan, J.C., Valent, A., Minty, A., Chalon, P., Lelias, J.M., Dumont, X., Ferrara, P., McKeon, F., and Caput, D. (1997) Monoallelically expressed gene related to $p 53$ at $1 \mathrm{p} 36$, a region frequently deleted in neuroblastoma and other human cancers. Cell 90, 809-819.

Kamb, A., Gruis, N.A., Weaver Feldhaus, J., Liu, Q., Harshman, K., Tavtigian, S.V., Stockert, E., Day, R.S., III, Johnson, B.E., and Skolnick, M.H. (1994) A cell cycle regulator potentially involved in genesis of many tumor types. Science 264, 436-440.

Karlbom, A. ., James, C.D., Boethius, J., Cavenee, W.K., Collins, V.P., Nordenskjold, M., and Larsson, C. (1993) Loss of heterozygosity in malignant gliomas involves at least three distinct regions on chromosome 10. Hum. Genet. 92, 169-174.

Kashiwazaki, H., Tonoki, H., Tada, M., Chiba, I., Shindoh, M., Totsuka, Y., Iggo, R., and Moriuchi, T. (1997) High frequency of p53 mutations in human oral epithelial dysplasia and primary squamous cell carcinoma detected by yeast functional assay. Oncogene 15, 2667-2674.

Kieser, A., Weich, H.A., Brandner, G., Marme, D., and Kolch, W. (1994) Mutant $\mathrm{p} 53$ potentiates protein kinase $\mathrm{C}$ induction of vascular endothelial growth factor expression. Oncogene 9, 963-969.

Kleihues, P., Burger, P.C., and Scheithauer, B.W. (1993) Histological typing of tumours of the central nervous system. Berlin: Springer Verlag.

Kluck, R.M., Martin, S.J., Hoffman, B.M., Zhou, J.S., Green, D.R., and Newmeyer, D.D. (1997) Cytochrome c activation of CPP32-like proteolysis plays a critical role in a Xenopus cell-free apoptosis system EMBO J. 16, 4639-4649.

Kondo, S., Barna, B.P., Kondo, Y., Tanaka, Y., Casey, G., Liu, J., Morimura, T.,
Kaakaji, R., Peterson, J.W., Werbel, B., and Barnett, G.H. (1996) WAF1/CIP1 increases the susceptibility of p53 non-functional malignant glioma cells to cisplatin-induced apoptosis. Oncogene 13, 1279-1285.

Kraus, J.A., Bolln, C., Wolf, H.K., Neumann, J., Kindermann, D., Fimmers, R., Forster, F., Baumann, A., and Schlegel, U. (1994) TP53 alterations and clinical outcome in low grade astrocytomas. Genes Chromosomes Cancer 10, 143-149.

Kraus, J.A., Koopmann, J., Kaskel, P., Maintz, D., Brandner, S., Schramm, J., Louis, D.N., Wiestler, O.D., and von Deimling, A. (1995) Shared allelic losses on chromosomes $1 p$ and $19 q$ suggest a common origin of oligodendroglioma and oligoastrocytoma. J. Neuropathol. Exp. Neurol. 54, 91-95.

Kroemer, G. (1997) The proto-oncogene Bcl-2 and its role in regulating apoptosis. Nat. Med. 3, 614-620.

Kubbutat, M.H., Jones, S.N., and Vousden, K.H. (1997) Regulation of p53 stability by Mdm2. Nature 387, 299-303.

Kyritsis, A.P., Bondy, M.L., Xiao, M., Berman, E.L., Cunningham, J.E., Lee, P.S., Levin, V.A., and Saya, H. (1994) Germline p53 gene mutations in subsets of glioma patients. J. Natl. Cancer. Inst. 86, 344-349.

Kyritsis, A.P., Zhang, B., Zhang, W., Xiao, M., Takeshima, H., Bondy, M.L., Cunningham, J.E., Levin, V.A., and Bruner, J. (1996) Mutations of the p16 gene in gliomas. Oncogene 12, 63-67.

Lang, F.F., Miller, D.C., Koslow, M., and Newcomb, E.W. (1994a) Pathways leading to glioblastoma multiforme: A molecular analysis of genetic alterations in 65 astrocytic tumors. J. Neurosurg. 81, 427-436.

Lang, F.F., Miller, D.C., Pisharody, S., Koslow, M., and Newcomb, E.W. (1994b) High frequency of p53 protein accumulation without p53 gene mutation in human juvenile pilocytic, low grade and anaplastic astrocytomas. Oncogene 9, 949-954.

Leenstra, S., Bijlsma, E.K., Troost, D., Oosting, J., Westerveld, A., Bosch, D.A., and Hulsebos, T.J. (1994) Allele loss on chromosomes 10 and 17p and epidermal growth factor receptor gene amplification in human malignant astrocytoma related to prognosis. Br. J. Cancer 70, 684-689.

Li, H., Bergeron, L., Cryns, V., Pasternack, M.S., Zhu, H., Shi, L., Greenberg, A., and Yuan, J. (1997) Activation of caspase-2 in apoptosis. J. Biol. Chem. 272, 21010-21017.

Li, J., Yen, C., Liaw, D., Podsypanina, K., Bose, S., Wang, S.I., Puc, J., Miliaresis, C., Rodgers, L., McCombie, R., Bigner, S.H., Giovanella, B.C., Ittmann, M., Tycko, B., Hibshoosh, H., Wigler, M.H., and Parsons, R. (1997) PTEN, a putative protein tyrosine phosphatase gene mutated in human brain, breast, and prostate cancer. Science 275, 1943-1947.

Liaw, D., Marsh, D.J., Li, J., Dahia, P.L., Wang, S.I., Zheng, Z., Bose, S., Call, K.M., Tsou, H.C., Peacocke, M., Eng, C., and Parsons, R. (1997) Germline mutations of the PTEN gene in Cowden disease, an inherited breast and thyroid cancer syndrome. Nat. Genet. 16, 64-67.

Litofsky, N.S., Hinton, D., and Raffel, C. (1994) The lack of a role for p53 in astrocytomas in pediatric patients. Neurosurgery 34, 967-972.

Liu, P.K., Kraus, E., Wu, T.A., Strong, L.C., and Tainsky, M.A. (1996) Analysis of genomic instability in Li-Fraumeni fibroblasts with germline p53 mutations. Oncogene 12, 2267-2278.

Liu, W., James, C.D., Frederick, L., Alderete, B.E., and Jenkins, R.B. (1997) PTEN/MMAC1 mutations and EGFR amplification in glioblastomas. Cancer Res. 57, 5254-5257.

Louis, D.N., Rubio, M.-P., Correa, K.M., Gusella, J.F., and von Deimling, A. (1993a) Molecular genetics of pediatric brain stem gliomas. Application of PCR techniques to small and archival brain tumor specimens. J. Neuropathol. Exp. Neurol. 52, 507-515.

Louis, D.N., von Deimling, A., Chung, R.Y., Rubio, M.P., Whaley, J.M., Eibl, R.H., Ohgaki, H., Wiestler, O.D., Thor, A.D., and Seizinger, B.R. (1993b) Comparative study of $\mathrm{p} 53$ gene and protein alterations in human astrocytic tumors. J. Neuropathol. Exp. Neurol. 52, 31-38.

Lowe, S.W., Ruley, H.E., Jacks, T., and Housman, D.E. (1993) p53-dependent apoptosis modulates the cytotoxicity of anticancer agents. Cell $\mathbf{7 4 ,}$ 
957-967.

Ludes Meyers, J.H., Subler, M.A., Shivakumar, C.V., Munoz, R.M., Jiang, P., Bigger, J.E., Brown, D.R., Deb, S.P., and Deb, S. (1996) Transcriptional activation of the human epidermal growth factor receptor promoter by human p53. Mol. Cell. Biol. 16, 6009-6019.

Mack, D.H., Vartikar, J., Pipas, J.M., and Laimins, L.A. (1993) Specific repression of TATA-mediated but not initiator-mediated transcription by wildtype p53. Nature 363, 281-283.

Mai, M., Yokomizo, A., Qian, C., Yang, P., Tindall, D.J., Smith, D.I., and Liu, W. (1998) Activation of p73 silent allele in lung cancer. Cancer Res. 58, 2347-2349.

Maintz, D., Fiedler, K., Koopmann, J., Rollbrocker, B., Nechev, S., Lenartz, D., Stangl, A.P., Louis, D.N., Schramm, J., Wiestler, O.D., and von Deimling, A. (1997) Molecular genetic evidence for subtypes of oligoastrocytomas. J. Neuropathol. Exp. Neurol. 56, 1098-1104.

Malkin, D., Li, F.P., Strong, L.C., Fraumeni, J.F., Jr., Nelson, C.E., Kim, D.H., Kassel, J., Gryka, M.A., Bischoff, F.Z., and Tainsky, M.A. et al. (1990) Germ line p53 mutations in a familial syndrome of breast cancer, sarcomas, and other neoplasms. Science 250, 1233-1238.

Margulies, L., and Sehgal, P.B. (1993) Modulation of the human interleukin-6 promoter (IL-6) and transcription factor C/EBP beta (NF-IL6) activity by p53 species. J. Biol. Chem. 268, 15096-15100.

Marsh, D.J., Dahia, P.L., Zheng, Z., Liaw, D., Parsons, R., Gorlin, R.J. and Eng, C. (1997) Germline mutations in PTEN are present in Bannayan-Zonana syndrome. Nat. Genet. 16, 333-334.

Martin, K., Trouche, D., Hagemeier, C., Sfrensen, T.S., La Thangue, N.B., and Kouzarides, T. (1995) Stimulation of E2F1/DP1 transcriptional activity by MDM2 oncoprotein. Nature 375, 691-694.

Mashiyama, S., Murakami, Y., Yoshimoto, T., Sekiya, T., and Hayashi, K. (1991) Detection of p53 gene mutations in human brain tumors by single-strand conformation polymorphism analysis of polymerase chain reaction products. Oncogene 6, 1313-1318.

Matsumoto, R., Tada, M., Nozaki, M., Zhang, C.-L., Sawamura, Y., and Abe, H. (1998) Short alternative splice transcripts of Mdm2 oncogene correlate to malignancy in human astrocytic neoplasms. Cancer Res. 58, 608-613.

Mercer, W.E., Shields, M.T., Amin, M., Sauve, G.J., Appella, E., Romano, J.W., and Ullrich, S.J. (1990) Negative growth regulation in a glioblastoma tumor cell line that conditionally expresses human wild-type p53. Proc. Natl. Acad. Sci. USA 87, 6166-6170.

Metzger, A.K., Sheffield, V.C., Duyk, G., Daneshvar, L., Edwards, M.S., and Cogen, P.H. (1991) Identification of a germ-line mutation in the p53 gene in a patient with an intracranial ependymona. Proc. Natl. Acad. Sci. USA 88, 7825-7829.

Meyer-Puttlitz, B., Hayashi, Y., Waha, A., Rollbrocker, B., Bostrom, J., Wiestler, O.D., Louis, D.N., Reifenberger, G., and von Deimling, A. (1997) Molecular genetic analysis of giant cell glioblastomas Am. J. Pathol. 151, 853-857.

Miyakoshi, J., Kitagawa, K., Yamagishi, N., Ohtsu, S., Day, R.S., III, and Takebe, H. (1997) Increased radiosensitivity of p16 gene-deleted human glioma cells after transfection with wild-type p16 gene. Jpn. J. Cancer Res. 88, 34-38.

Miyashita, T., and Reed, J.C. (1995) Tumor suppressor p53 is a direct transcriptional activator of the human bax gene. Cell 80, 293-299.

Miyashita, T., Harigai, M., Hanada, M., and Reed, J.C. (1994) Identification of a p53-dependent negative response element in the bcl-2 gene. Cancer Res. 54, 3131-3135.

Mollenhauer, J., Wiemann, S., Scheurlen, W., Korn, B., Hayashi, Y., Wilgenbus, K.K., von Deimling, A., and Poustka, A. (1997) DMBT1, a new member of the SRCR superfamily, on chromosome 10q25.3-26.1 is deleted in malignant brain tumours. Nat. Genet. 17, 32-39.

Momand, J., Zambetti, G.P., Olson, D.C., George, D.L., and Levine, A.J. (1992) The mdm-2 oncogene product forms a complex with the $\mathrm{p} 53$ protein and inhibits p53-mediated transactivation. Cell 69, 1237-1245.
Morris, G.F., Bischoff, J.R., and Mathews, M.B. (1996) Transcriptional activation of the human proliferating-cell nuclear antigen promoter by $\mathrm{p} 53$. Proc. Natl. Acad. Sci. USA 93, 895-899.

Moulton, T., Samara, G., Chung, W. ., Yuan, L., Desai, R., Sisti, M., Bruce, J., and Tycko, B. (1995) MTS1/p16/CDKN2 lesions in primary glioblastoma multiforme. Am. J. Pathol. 146, 613-619.

Mukhopadhyay, D., Tsiokas, L., and Sukhatme, V.P. (1995) Wild-type p53 and $v$-Src exert opposing influences on human vascular endothelial growth factor gene expression. Cancer Res. 55, 6161-6165.

Muller, W., Afra, D., and Schroder, R. (1977) Supratentorial recurrence of gliomas. Morphological studies in relation to time intervals with astrocytomas. Acta Neurochir. 37, 75-91.

Myers, M.P., Stolarov, J.P., Eng, C., Li, J., Wang, S.I., Wigler, M.H., Parsons, R., and Tonks, N.K. (1997) P-TEN, the tumor suppressor from human chromosome $10 \mathrm{q} 23$, is a dual-specificity phosphatase. Proc. Natl. Acad. Sci. USA 94, 9052-9057.

Nakamura, H., Yoshida, M., Tsuiki, H., Ito, K., Ueno, M., Nakao, M., Oka, K., Tada, M., Kochi, M., Kuratsu, J.-I., Ushio, Y., and Saya, H. (1998) Identification of a human homolog of the Drosophila neuralized gene within the 10q25.1 malignant astrocytoma deletion region. Oncogene 16, 1009-1019.

Newcomb, E.W., Madonia, W.J., Pisharody, S., Lang, F.F., Koslow, M., and Miller, D.C. (1993) A correlative study of p53 protein alteration and p53 gene mutation in glioblastoma multiforme. Brain Pathol. 3, 229-235.

Nishikawa, R., Ji, X.D., Harmon, R.C., Lazar, C.S., Gill, G.N., Cavenee, W.K., and Huang, H.J. (1994) A mutant epidermal growth factor receptor common in human glioma confers enhanced tumorigenicity. Proc. Natl. Acad. Sci. USA 91, 7727-7731.

Nomoto, S., Haruki, N., Kondo, M., Konishi, H., Takahashi, T., Takahashi, T., and Takahashi, T. (1998) Search for mutations and examination of allelic expression imbalance of the p73 gene at 1 p36.33 in human lung cancers. Cancer Res. 58, 1380-1383.

Nozaki, M., Tada, M., Matsumoto, R., Sawamura, Y., Abe, H., and Iggo, R.D. (1998) Rare occurrence of inactivating p53 gene mutations in primary non-astrocytic tumors of the central nervous system: Reappraisal by yeast functional assay. Acta Neuropathol. 95, 291-296.

Ohgaki, H., Eibl, R.H., Wiestler, O.D., Yasargil, M.G., Newcomb, E.W., and Kleihues, P. (1991) p53 mutations in nonastrocytic human brain tumors. Cancer Res. 51, 6202-6205.

Ohgaki, H., Eibl, R.H., Schwab, M., Reichel, M.B., Mariani, L., Gehring, M., Petersen, I., Holl, T., Wiestler, O.D., and Kleihues, P. (1993) Mutations of the p53 tumor suppressor gene in neoplasms of the human nervous system. Mol. Carcinog. 8, 74-80.

Okamoto, K., and Beach, D. (1994) Cyclin G is a transcriptional target of the p53 tumor suppressor protein. EMBO J. 13, 4816-4822.

Olschwang, S., Serova-Sinilnikova, O.M., Lenoir, G.M., and Thomas, G. (1998) PTEN germ-line mutations in juvenile polyposis coli. Nat. Genet. 18, 12-14.

Ono, Y., Tamiya, T., Ichikawa, T., Kunishio, K., Matsumoto, K., Furuta, T., Ohmoto, T., Ueki, K., and Louis, D.N. (1996) Malignant astrocytomas with homozygous CDKN2/p16 gene deletions have higher Ki-67 proliferation indices. J. Neuropathol. Exp. Neurol. 55, 1026-1031.

Osada, M., Ohba, M., Kawahara, C., Ishioka, C., Kanamaru, R., Katoh, I., Ikawa, Y., Nimura, Y., Nakagawara, A., Obinata, M., and Ikawa, S. (1998) Cloning and functional analysis of human p51, which structurally and functionally resembles p53. Nat. Med. 4, 839-843.

Patt, S., Gries, H., Giraldo, M., Cervos Navarro, J., Martin, H., Janisch, W., and Brockmoller, J. (1996) p53 gene mutations in human astrocytic brain tumors including pilocytic astrocytomas. Hum. Pathol. 27, 586-589.

Penar, P.L., Khoshyomn, S., Bhushan, A., and Tritton, T.R. (1997) Inhibition of epidermal growth factor receptor-associated tyrosine kinase blocks glioblastoma invasion of the brain. Neurosurgery 40, 141-151. 
Polyak, K., Waldman, T., He, T.C., Kinzler, K.W., and Vogelstein, B. (1996) Genetic determinants of p53-induced apoptosis and growth arrest. Genes Dev. 10, 1945-1952.

Ragimov, N., Krauskopf, A., Navot, N., Rotter, V., Oren, M., and Aloni, Y. (1993) Wild-type but not mutant p53 can repress transcription initiation in vitro by interfering with the binding of basal transcription factors to the TATA motif. Oncogene 8, 1183-1193.

Rainov, N.G., Dobberstein, K.-U., Fittkau, M., Bahn, H., Holzhausen, H.-J., Gantchev, L., and Burkert, W. (1995) Absence of p53 autoantibodies in sera from glioma patients. Clin. Cancer Res. 1, 775-781.

Rasheed, B.K., McLendon, R.E., Herndon, J.E., Friedman, H.S., Friedman, A.H., Bigner, D.D., and Bigner, S.H. (1994) Alterations of the TP53 gene in human gliomas. Cancer Res. 54, 1324-1330.

Rasheed, B.K., McLendon, R.E., Friedman, H.S., Friedman, A.H., Fuchs, H.E., Bigner, D.D., and Bigner, S.H. (1995) Chromosome 10 deletion mapping in human gliomas: a common deletion region in 10q25. Oncogene 10, 2243-2246.

Rasheed, B.K., Stenzel, T.T., McLendon, R.E., Parsons, R., Friedman, A.H., Friedman, H.S., Bigner, D.D., and Bigner, S.H. (1997) PTEN gene mutations are seen in high-grade but not in low-grade gliomas. Cancer Res. 57, 4187-4190.

Reed, J.C. (1997) Double identity for proteins of the Bcl-2 family. Nature 387, 773-776.

Reifenberger, G., Reifenberger, J., Ichimura, K., Meltzer, P.S., and Collins, V.P. (1994) Amplification of multiple genes from chromosomal region 12q1314 in human malignant gliomas: preliminary mapping of the amplicons shows preferential involvement of CDK4, SAS, and MDM2. Cancer Res. 54, 4299-4303.

Reifenberger, J., Reifenberger, G., Liu, L., James, C.D., Wechsler, W., and Collins, V.P. (1994) Molecular genetic analysis of oligodendroglial tumors shows preferential allelic deletions on $19 q$ and 1p. Am. J. Pathol. 145, 1175-1190.

Reifenberger, J., Ring, G.U., Gies, U., Cobbers, L., Oberstrass, J., An, H.X., Niederacher, D., Wechsler, W., and Reifenberger, G. (1996) Analysis of p53 mutation and epidermal growth factor receptor amplification in recurrent gliomas with malignant progression. J. Neuropathol. Exp. Neurol. 55, 822-831.

Sakuma, S., Saya, H., Tada, M., Nakao, M., Fujiwara, T., Roth, J.A., Sawamura, Y., Shinohe, Y., and Abe, H. (1996) Receptor protein tyrosine kinase DDR is up-regulated by p53 protein. FEBS Lett. 398, 165-169.

Sandig, V., Brand, K., Herwig, S., Lukas, J., Bartek, J., and Strauss, M. (1997) Adenovirally transferred $\mathrm{p} 16 \mathrm{INK} 4 / \mathrm{CDKN} 2$ and $\mathrm{p} 53$ genes cooperate to induce apoptotic tumor cell death. Nat. Med. 3, 313-319.

Santhanam, U., Ray, A., and Sehgal, P.B. (1991) Repression of the interleukin 6 gene promoter by $\mathrm{p} 53$ and the retinoblastoma susceptibility gene product. Proc. Natl. Acad. Sci. USA 88, 7605-7609.

Sarkar, F.H., Kupsky, W.J., Li, Y.-W., and Sreepathi, P. (1994) Analysis of p53 gene mutations in human gliomas by polymerase chain reaction-based single-strand conformation polymorphism and DNA sequencing. Diag. Mol. Pathol. 3, 2-8.

Saxena, A., Clark, W.C., Robertson, J.T., Ikejiri, B., Oldfield, E.H., and Ali, I.U. (1992) Evidence for the involvement of a potential second tumor suppressor gene on chromosome 17 distinct from $\mathrm{p} 53$ in malignant astrocytomas. Cancer Res. 52, 6716-6721.

Saylors, R.L., III, Sidransky, D., Friedman, H.S., Bigner, S.H., Bigner, D.D., Vogelstein, B., and Brodeur, G.M. (1991) Infrequent p53 gene mutations in medulloblastomas. Cancer Res. 51, 4721-4723.

Scherer, S.J., Welter, C., Zang, K.D., and Dooley, S. (1996) Specific in vitro binding of p53 to the promoter region of the human mismatch repair gene hMSH2. Biochem. Biophys. Res. Commun. 221, 722-728.

Schiffer, D., Cavalla, P., Di Sapio, A., Giordana, M.T., and Mauro, A. (1995) Mutations and immunohistochemistry of p53 and proliferation markers in astrocytic tumors of childhood. Childs Nerv. Syst. 11, 517-522.

Schlegel, J., Scherthan, H., Arens, N., Stumm, G., and Kiessling, M. (1996) Detection of complex genetic alterations in human glioblastoma multiforme using comparative genomic hybridization. J. Neuropathol. Exp. Neurol. 55, 81-87.

Schmidt, E.E., Ichimura, K., Reifenberger, G., and Collins, V.P. (1994) CDKN2 (p16/MTS1) gene deletion or CDK4 amplification occurs in the majority of glioblastomas. Cancer Res. 54, 6321-6324.

Schmidt, E.E., Ichimura, K., Messerle, K.R., Goike, H.M., and Collins, V.P. (1997) Infrequent methylation of CDKN2A(MTS1/p16) and rare mutation of both CDKN2A and CDKN2B(MTS2/p15) in primary astrocytic tumours. Br. J. Cancer 75, 2-8.

Serrano, M., Hannon, G.J., and Beach, D. (1993) A new regulatory motif in cell-cycle control causing specific inhibition of cyclin D/CDK4. Nature 366, 704-707.

Shin, T.H., Paterson, A.J., and Kudlow, J.E. (1995) p53 stimulates transcription from the human transforming growth factor $\alpha$ promoter: A potential growth-stimulatory role for p53. Mol. Cell. Biol. 15, 4694-4701.

Sidransky, D., Mikkelsen, T., Schwechheimer, K., Rosenblum, M.L., Cavenee, W., and Vogelstein, B. (1992) Clonal expansion of p53 mutant cells is associated with brain tumor progression. Nature 355, 846-847.

Sonoda, Y., Yoshimoto, T., and Sekiya, T. (1995) Homozygous deletion of the MTS1/p16 and MTS2/p15 genes and amplification of the CDK4 gene in glioma. Oncogene 11, 2145-2149.

Sorby, M., and Ostman, A. (1996) Protein-tyrosine phosphatase-mediated decrease of epidermal growth factor and platelet-derived growth factor receptor tyrosine phosphorylation in high cell density cultures. J. Biol. Chem. 271, 10963-10966.

Steck, P.A., Pershouse, M.A., Jasser, S.A., Yung, W.K., Lin, H., Ligon, A.H., Langford, L.A., Baumgard, M.L., Hattier, T., Davis, T., Frye, C., Hu, R., Swedlund, B., Teng, D.H., and Tavtigian, S.V. (1997) Identification of a candidate tumour suppressor gene, MMAC1, at chromosome 10q23.3 that is mutated in multiple advanced cancers. Nat. Genet. 15, 356-362.

Strasser, A., Harris, A.W., Jacks, T., and Cory, S. (1994) DNA damage can induce apoptosis in proliferating lymphoid cells via p53-independent mechanisms inhibitable by Bcl-2. Cell 79, 329-339.

Sunahara, M., Ichimiya, S., Nimura, Y., Takada, N., Sakiyama, S., Sato, Y., Todo, S., Adachi, W., Amano, J., and Nakagawara, A. (1998) Mutational analysis of the p73 gene localized at chromosome 1 p36.3 in colorectal carcinomas. Int. J. Oncol. 13, 319-323.

Sure, U., Ruedi, D., Tachibana, O., Yonekawa, Y., Ohgaki, H., Kleihues, P., and Hegi, M.E. (1997) Determination of p53 mutations, EGFR overexpression, and loss of p16 expression in pediatric glioblastomas J. Neuropathol. Exp. Neurol. 56, 782-789.

Tada, M., Iggo, R.D., Ishii, N., Shinohe, Y., Sakuma, S., Estreicher, A., Sawamura, Y., and Abe, H. (1996) Clonality and stability of the p53 gene in human astrocytic tumor cells: quantitative analysis of p53 gene mutations by yeast functional assay. Int. J. Cancer 67, 447-450.

Tada, M., Iggo, R.D., Waridel, F., Nozaki, M., Matsumoto, R., Sawamura, Y., Shinohe, Y., Ikeda, J., and Abe, H. (1997) Reappraisal of p53 mutations in human malignant astrocytic neoplasms by $\mathrm{p} 53$ functional assay: comparison with conventional structural analyses. Mol. Carcinog. 18, 171-176.

Tada, M., Matsumoto, R., Iggo, R.D., Onimaru, R., Shirato, H., Sawamura, Y., and Shinohe, Y. (1998) Selective sensitivity to radiation of cerebral glioblastomas harboring p53 mutation. Cancer Res. 58, 1793-1797.

Takahashi, H., Ichimiya, S., Nimura, Y., Watanabe, M., Furusato, M., Wakui, S., Yatani, R., Aizawa, S., and Nakagawara, A. (1998) Mutation, allelotyping, and transcription analyses of the p73 gene in prostatic carcinoma. Cancer Res. 58, 2076-2077.

Tamura, M., Gu, J., Matsumoto, K., Aota, S., Parsons, R., and Yamada, K.M. (1998) Inhibition of cell migration, spreading, and focal adhesions by tumor suppressor PTEN. Science 280, 1614-1617. 
Tang, P., Steck, P.A., and Yung, W.K. (1997) The autocrine loop of TGFalpha/EGFR and brain tumors. J. Neurooncol. 35, 303-314.

Tenan, M., Colombo, B.M., Pollo, B., Cajola, L., Broggi, G., and Finocchiaro, G. (1994) p53 mutations and microsatellite analysis of loss of heterozygosity in malignant gliomas. Cancer Genet. Cytogenet. 74, 139-143.

Tenan, M., Benedetti, S., and Finocchiaro, G. (1995) Deletion and transfection analysis of the p15/MTS2 gene in malignant gliomas. Biochem. Biophys. Res. Commun. 217, 195-202.

Teng, D.H.F., Hu, R., Lin, H., Davis, T., lliev, D., Frye, C., Swedlund, B., Hansen, K.L., Vinson, V.L., Gumpper, K.L., Ellis, L., Elnaggar, A., Frazier, M., Jasser, S., Langford, L.A., Lee, J., Mills, G.B., Pershouse, M.A., Pollack, R.E., Tornos, C., Troncoso, P., Yung, W.K., Fujii, G., Berson, A., and Bookstein, R. (1997) MMAC1/PTEN mutations in primary tumor specimens and tumor cell lines. Cancer Res. 57, 5221-5225.

Tohma, Y., Gratas, C., Biernat, W., Peraud, A., Fukuda, M., Yonekawa, Y., Kleihues, P., and Ohgaki, H. (1998) PTEN (MMAC1) mutations are frequent in primary glioblastomas (de novo) but not in secondary glioblastomas. J. Neuropathol. Exp. Neurol. 57, 684-689.

Trink, B., Okami, K., Wu, L., Sriuranpong, V., Jen, J., and Sidransky, D. (1998) A new human 553 homologue. Nat. Med. 4, 747-745.

Tsumanuma, I., Sato, M., Okazaki, H., Tanaka, R., Washiyama, K., Kawasaki, T., and Kumanishi, T. (1995) The analysis of p53 tumor suppressor gene in pineal parenchymal tumors. Noshuyo Byori 12, 39-43.

Tsuzuki, T., Tsunoda, S., Sakaki, T., Konishi, N., Hiasa, Y., and Nakamura, M. (1996) Alterations of retinoblastoma, p53, p16(CDKN2), and p15 genes in human astrocytomas. Cancer 78, 287-293.

Ueba, T., Nosaka, T., Takahashi, J.A., Shibata, F., Florkiewicz, R.Z., Vogelstein, B., Oda, Y., Kikuchi, H., and Hatanaka, M. (1994) Transcriptional regulation of basic fibroblast growth factor gene by $\mathrm{p} 53$ in human glioblastoma and hepatocellular carcinoma cells. Proc. Natl. Acad. Sci. USA 91, 9009-9013.

Ueki, K., Ono, Y., Henson, J.W., Efird, J.T., von Deimling, A., and Louis, D.N. (1996) CDKN2/p16 or RB alterations occur in the majority of glioblastomas and are inversely correlated. Cancer Res. 56, 150-153.

Uhrbom, L., Nister, M., and Westermark, B. (1997) Induction of senescence in human malignant glioma cells by p16INK4A. Oncogene 15, 505-514.

Van Meir, E.G., Roemer, K., Diserens, A. ., Kikuchi, T., Rempel, S.A., Haas, M., Huang, H.-J., Friedmann, T., de Tribolet, N., and Cavenee, W.K. (1995) Single cell monitoring of growth arrest and morphological changes induced by transfer of wild-type p53 alleles to glioblastoma cells. Proc. Natl. Acad. Sci. USA 92, 1008-1012.

van Meyel, D.J., Ramsay, D.A., Casson, A.G., Keeney, M., Chambers, A.F., and Cairncross, J.G. (1994) p53 mutation, expression, and DNA ploidy in evolving gliomas: Evidence for two pathways of progression. J. Natl. Cancer Inst. 86, 1011-1017.

von Deimling, A., Eibl, R.H., Ohgaki, H., Louis, D.N., von Ammon, K., Petersen, I., Kleihues, P., Chung, R.Y., Wiestler, O.D., and Seizinger, B.R. (1992a) p53 mutations are associated with 17 p allelic loss in grade II and grade III astrocytoma. Cancer Res. 52, 2987-2990.

von Deimling, A., Louis, D.N., von Ammon, K., Petersen, I., Hoell, T., Chung, R.Y., Martuza, R.L., Schoenfeld, D.A., Yasargil, M.G., and Wiestler, O.D. (1992b) Association of epidermal growth factor receptor gene amplification with loss of chromosome 10 in human glioblastoma multiforme. J. Neurosurg. 77, 295-301.

von Deimling, A., von Ammon, K., Schoenfeld, D., Wiestler, O.D., Seizinger, B.R., and Louis, D.N. (1993) Subsets of glioblastoma multiforme defined by molecular genetic analysis. Brain Pathol. 3, 19-26.
Wagenknecht, B., Trepel, M., von Deimling, A., Grimmel, C., Rollbrocker, B., Hayashi, Y., Lang, F., Dichgans, J., Gulbins, E., and Weller, M. (1997) p53 accumulation promotes dephosphorylation and proteolytic cleavage of retinoblastoma protein in human malignant glioma cells. Cell. Physiol. Biochem. 7, 304-311.

Wahl, A.F., Donaldson, K.L., Fairchild, C., Lee, F.Y., Foster, S.A., Demers, G.W., and Galloway, D.A. (1996) Loss of normal p53 function confers sensitization to Taxol by increasing G2/M arrest and apoptosis. Nat. Med. 2, 72-79.

Waldman, T., Zhang, Y., Dillehay, L., Yu, J., Kinzler, K., Vogelstein, B., and Williams, J. (1997) Cell-cycle arrest versus cell death in cancer therapy. Nat. Med. 3, 1034-1036.

Wang, S.I., Puc, J., Li, J., Bruce, J.N., Cairns, P., Sidransky, D., and Parsons, R. (1997) Somatic mutations of PTEN in glioblastoma multiforme. Cancer Res. 57, 4183-4186.

Waridel, F., Estreicher, A., Bron, L., Flaman, J.M., Fontolliet, C., Monnier, P., Frebourg, T., and Iggo, R. (1997) Field cancerisation and polyclonal p53 mutation in the upper aero-digestive tract. Oncogene 14, 163-169.

Watanabe, K., Tachibana, O., Sata, K., Yonekawa, Y., Kleihues, P., and Ohgaki, H. (1996) Overexpression of the EGF receptor and p53 mutations are mutually exclusive in the evolution of primary and secondary glioblastomas. Brain Pathol. 6, 217-223.

Watanabe, K., Sato, K., Biernat, W., Tachibana, O., Vonammon, K., Ogata, N., Yonekawa, Y., Kleihues, P., and Ohgaki, H. (1997) Incidence and timing of p53 mutations during astrocytoma progression in patients with multiple biopsies. Clin. Cancer Res. 3, 523-530.

Werner, H., Karnieli, E., Rauscher, F.J., and LeRoith, D. (1996) Wild-type and mutant p53 differentially regulate transcription of the insulin-like growth factor I receptor gene. Proc. Natl. Acad. Sci. USA 93, 8318-8323.

Willert, J.R., Daneshvar, L., Sheffield, V.C., and Cogen, P.H. (1995) Deletion of chromosome arm 17p DNA sequences in pediatric high-grade and juvenile pilocytic astrocytomas. Genes Chromosomes Cancer 12, 165-172.

Wu, J.K., Ye, Z., and Darras, B.T. (1993) Frequency of p53 tumor suppressor gene mutations in human primary brain tumors. Neurosurgery 33, 824-830.

Xiao, Z.X., Chen, J., Levine, A.J., Modjtahedi, N., Xing, J., Sellers, W.R., and Livingston, D.M. (1995) Interaction between the retinoblastoma protein and the oncoprotein MDM2. Nature 375, 694-698.

Yahanda, A.M., Bruner, J.M., Donehower, L.A., and Morrison, R.S. (1995) Astrocytes derived from p53-deficient mice provide a multistep in vitro model for development of malignant gliomas. Mol. Cell. Biol. 15, 4249-4259.

Yount, G.L., Haas-Kogan, D.A., Vidair, C.A., Haas, M., Dewey, W.C., and Israel, M.A. (1996) Cell cycle synchrony unmasks the influence of p53 function on radiosensitivity of human glioblastoma cells. Cancer. Res. 56, 500-506.

Zastawny, R.L., Salvino, R., Chen, J., Benchimol, S., and Ling, V. (1993) The core promoter region of the $\mathrm{P}$-glycoprotein gene is sufficient to confer differential responsiveness to wild-type and mutant p53. Oncogene 8 , 1529-1535.

Zhang, L., Kashanchi, F., Zhan, Q., Zhan, S., Brady, J.N., Fornace, A.J., Seth, P., and Helman, L.J. (1996) Regulation of insulin-like growth factor II P3 promotor by p53: A potential mechanism for tumorigenesis. Cancer Res. 56, 1367-1373.

Zhang, S., Feng, X., Koga, H., Ichikawa, T., Abe, S., and Kumanishi, T. (1993) p53 gene mutations in pontine gliomas of juvenile onset. Biochem. Biophys. Res. Commun. 196, 851-857. 